\title{
Señores de la tierra y negros colonos en Piura y Querecotillo Apuntes sobre la lucha por la libertad y los derechos civiles en
el proceso de nacimiento de la república entre 1825-1855
}

\begin{abstract}
RESUMEN
En esta investigación avanzamos en el conocimiento mucho más específico sobre las formas que asume la esclavitud republicana y algunas experiencias de resistencia social por la población negra y liberta y la práctica del sistema del abolicionismo realizados en una coyuntura de construcción de la república en un espacio regional como es la provincia de Piura. A través del estudio de casos examinamos el camino que asumieron los afrodescendientes usando las leyes y la fuerza social de sus representantes en los tribunales para destruir las cadenas que los oprimían bajo la nueva república criolla. Se revisa las manumisiones por compraventa y gracia del amo pero también otras formas de conquista de la libertad como es el movimiento social del bandolerismo en el contexto de la guerra de la Independencia. De igual forma se presenta y examina la experiencia política que vivirán las castas populares asentados al interior del latifundio de Tangarará y la resistencia política al proyecto de supresión del pueblo de Querecotillo dirigido por el coronel del ejército don Francisco Xavier Fernández de Paredes.
\end{abstract}

Palabras Clave: Piura; negros; castas; hacienda; abolicionismo.

\section{Lords of the land and black settlers in Piura and Querecotillo. Notes about freedom struggles and civil rights in the republic birth process between 1825-1855}

\begin{abstract}
In this research we progress towards a more specific understanding about republican slavery forms, social resistance experiences of the slaved and freed black population, and practice of the abolitionist system carried out in a situation of building up the republic in a regional space: the province of Piura. Through case studies, we examine the path that afro-descendants assumed using laws and social force of their representatives in the courts to destroy the chains that oppressed them under the new creole republic. We review liberations through purchase, sell, and master's grace, but also other forms of freedom conquest as the banditry social movement in a independence war context. Likewise, we present and examine the political experience that will be lived by popular castes settled within Tangararás latifundia, and political resistance to the elimination project of the Querecotillo town led by the army colonel Don Francisco Xavier Fernández de Paredes.
\end{abstract}

KEYwords: Piura; black people; castes; hacienda; abolitionism. 


\section{A modo de Introducción}

1. Después de la batalla de Ayacucho (1824) se impuso en la costa norte una nueva división interna del territorio para garantizar y administrar un nuevo ordenamiento político y administrativo republicano. Esta vez, desde la ciudad de Lima se busca reforzar la frontera norte con la nueva república de Ecuador (Jean Piel 1991: 423-437 y Susana Aldana 2002: 104-110)

En la segunda década del siglo XIX se había reorganizado una nueva elite en Piura; emerge una clase política que busca organizar un nuevo régimen político interno para construir un nuevo orden social en una geografía de fuerte contraste territorial y demográfico. Piura es un microespacio clave para la comunicación con USA y Europa. Las imágenes de San Martín, Torre Tagle y Riva Agüero en la vida sociocultural de los pueblos, haciendas y comunidades indígenas de Piura son muy efímeras. Todo lo contrario, ocurre con Bolívar y Santa Cruz. Juan Paz ha ubicado información muy interesante para este tiempo. Desde Piura un sector de la elite abrazó el modelo político de la confederación llegando a crearse la provincia litoral de Piura en 1837. Para estos años este espacio territorial concentraba un poco más de 70 mil habitantes, de los cuales 38 mil pertenecían a la casta indígena y 32 mil a los llamados pardos, mestizos y blancos. El proyecto político de Santa Cruz fracasa y retorna al poder la otra facción de la elite de posiciones conservadoras. En la historiografía local es muy poco lo que se sabe sobre esta coyuntura que vino luego del gobierno de Bolívar y Gamarra, es decir, del caudillismo militarista. En los pocos libros y manuales se evidencia una tendencia a entronizar el olvido de este acontecimiento político y simbólico que denotaba una prueba de la alta politización que había asumido la población de Piura (Paz 2002: 12-40)

¿Fue la división político-administrativo del Partido de Piura impuesto por los Borbones el modelo asumido por los republicanos después de 1824? $\mathrm{Si}$ es así, entonces ¿Cuáles fueron los cambios y su evolución histórica? A la fecha no existe una historia de las haciendas, de las comunidades indígenas, de las doctrinas, de los pueblos y caseríos, ¿de los centros poblados rurales y urbanos? Por tanto ¿Cuáles fueron los criterios de la división, asentamiento y fijación de los pueblos en los valles costeños y serra- nos? ¿Hubo un debate u defensa de intereses locales en el tiempo histórico de los Borbones? ¿Se produjo una resistencia en el tránsito del corregimiento a las Subdelegaciones-Intendencias? ¿Qué tipo de acuerdos se realizaron entre los grupos de interés, comerciales y territoriales para la adopción en la vida política cotidiana de conceptos republicanos como la de la igualdad y la democracia, el papel de las leyes y de la nueva política educativa?

La creación de la provincia Litoral (1837) y del departamento de Piura (1861) modificaron las fisonomías territoriales tradicionales y marcaron el tránsito hacia otra moderna, racional y republicana. ¿Cuál fue el peso de la economía del guano, del caudillaje militar, de la confederación liderada por Santa Cruz y del proyecto militar de Castilla en la evolución política-administrativa de Piura? ¿Continuidad o cambio? Y a nivel interno ¿cómo se produjo la nueva reconfiguración de las haciendas, de las tierras de comunidad, de los ejidos municipales y los territorios del Estado nacional? En este escrito buscamos plantear algunas ideas preliminares examinando la experiencia política del pueblo de Querecotillo.

Ahora bien, desde la perspectiva de la sociedad, registramos que la vida social de los esclavos/as es muy compleja en estos años porque la guerra contra España desde 1812 había provocado la agudización del despertar de muchos odios y envidias, triunfando y explayándose las sensibilidades de todas las capas sociales y emergiendo toda una variedad de emociones que van a envolver los comportamientos de las gentes guiados no siempre por la racionalidad. Entre blancos, indígenas y afrodescendientes madura una socialización emotiva antiespańola y en la que la cultura y la civilización europea empieza a imponer sus nuevos patrones de sociabilidad y de construcción de una nueva sociedad desigual dependiente de las normas religiosas y de una legalidad todavía borbónica a comienzos del siglo xIx. Es al interior de los espacios que ofrecían el marco legal vigente y la instalación y funcionamiento temprano de las instituciones republicanas que los negros esclavos buscarían aplicar alternativas favorables a sus propios intereses y lograr alcanzar el sueño de la libertad (César Espinoza 2005: 235-255). ${ }^{1}$

1 También puede consultarse a Susana Aldana 1997: 157-164 y Zózimo Domínguez 2009: 61-80. 
En efecto, es contra estas iniciativas de manumisión espontánea y racionales que reaccionaron los grandes propietarios de tierras y un grupo de comerciantes agrupados en la ciudad de Piura y Sullana. Uno de los casos simbólicos que examinamos en esta ocasión es el grave enfrentamiento producido entre el coronel don Francisco Xavier Fernández de Paredes, dueño del latifundio ganadero y algodonero de Tangarará, y un grupo aguerrido de colonos indígenas y de afrodescendientes que se habían apoderado de un sector de tierras de humedad para refundar un nuevo pueblo rural llamado Querecotillo para otorgarle la categoría política de junta municipal y designar a sus representantes y gobernadores locales. Abolicionistas y esclavistas recurren a la batalla legal pero también a las decisiones que toma el gobierno nacional para equilibrar el peso señorial de pequeñas elites regionales.

Los esclavos y las esclavas de la ciudad de SM de Piura se plantearon desde 1821 comprar su libertad a los precios señalados por los jueces de paz para luego ampliar esta operación judicial con otros miembros de su propia familia. Pero a este accionar se sumaron otras modalidades de resistencia y de combate a la esclavitud, como el bandolerismo social, que se vuelve endémico con la crisis borbónica y la formación naciente del Estado y su presencia en la provincia de Piura en la primera mitad del siglo XIX.

2. En la provincia de Piura la ruptura del nexo colonial con España dio inicio a los procesos de creación y formación de la región, la nación y del Estado. Fue un proceso complejo que inició Torre Tagle desde la ciudad de Trujillo y el general San Martín desde la ciudad de Lima. El modelo de la práctica política de ambos personajes coincidió en realizarlo gradualmente desde arriba, y con el apoyo del Ejército y un sector de la población coordinando y sumando a este proyecto político a los líderes locales criollos e imponiéndoles el modelo político de la junta de gobierno con vecinos y ciudadanos de Piura. En efecto, este proceso político entonces fue dirigido por una alianza temporal de las clases y fracciones dominantes criollas, mestizas, indígenas y de afrodescendientes en situación de dependencia de Trujillo y Lima, buscando mantener una estructura social que garantizara su situación de poder, y conservar a las poblaciones preexistentes en una posición de dominación, subal- ternización y explotación. Es en esta coyuntura histórica que los negros esclavos y libertos se movilizan y dinamizan su presencia en la actividad política y judicial para imponerse y lograr ampliar sus espacios y esferas sociales que garanticen la continuidad de su estatus obtenido y la permanencia de sus familias al interior de la ciudad de San Miguel de Piura y también al interior de las grandes haciendas pero esta vez protegidos por la nueva legislación republicana dictada e implementada entre los gobiernos de dos militares, el general José de San Martín y el mariscal Ramón Castilla. Hacendados pro-esclavistas y negros esclavos abolicionistas cruzan sus plumas con ideas y leyes pero también mostrando la fuerza de la acción política usando al ejército o la movilización social de los colonos campesinos para lograr la hegemonía local y regional para seguir ensayando la construcción del Estado nacional.

Con la información obtenida en el Archivo Regional de Piura y el Archivo General de la Nación, podemos postular la tesis de que el proceso de descolonización piurana fue heredera y continuadora de los mecanismos de producción de identidad y de diferenciación colonial borbónica. El resultado de este tránsito de la Colonia a la República fue una reconfiguración (no una transformación) de la jerarquía étnico-social en la que ahora continua una elite blanca criolla que sirve de base de articulación al proyecto mayor que se impulsa por los caudillos militares con el discurso de la república y de construcción de un Estado-Nación, orientado por la cultura euroccidental, monocultural y homogénea. ${ }^{2}$

De esta forma, al interior de este complejo contexto sociopolítico encontramos la experiencia política singular de la lucha contra el esclavismo por parte de los colonos indígenas y de los labradores afrodescendientes del pueblo de Querecotillo que usando las propias leyes de la república consiguen triunfar en una compleja batalla legal y política contra el poderoso latifundista y coronel del ejército y dueño de la hacienda de Tangarará, ubicado en el valle de La Chira. ${ }^{3}$ Por otra parte, también registramos otra for-

2 La historiografía sobre el nacimiento del Estado y la nación en el Perú es muy amplia. He consultado a Mc Evoy, Carmen y Gabriel Cid 2016: 313-336; Mc Evoy, Carmen 2013; Gabriela Chiaramonti 2005; Aljovín de Losada, Cristóbal y Jacobsen, Nils 2007.

3 Sobre la historia agraria y social del valle de La Chira puede consultarse César Espinoza 2013. 
ma de combate y resistencia al esclavismo por parte de un sector de afrodescendientes, mestizos y blancos desarraigados que optaron por la práctica del bandolerismo social en su propósito de conseguir la libertad y de quebrar el sistema virreinal que oprimía a toda la región norte del Perú borbónico y republicano. ${ }^{4}$

Estudio de caso A. Don Francisco Xavier Fernández de Paredes, dueño de la hacienda de Tangarará se enfrenta a los colonos indígenas y afrodescendientes campesinos de Querecotillo en su intento de expulsarlos y de liquidar el gobierno municipal organizado entre 1825 y 1832.5

El coronel don Francisco Xavier Fernández de Paredes, propietario del latifundio de Tangarará y antiguo noble limeño y monárquico liberal busca defender las fronteras de su propiedad rural que ocupa casi toda la margen derecha entre Poechos y Amotape, en el río de La Chira, del accionar económico y político de un grupo de labradores de la tierra que se habían asentado en el sitio de Querecotillo ganando una extensión de tierras «húmedas» que antiguamente estaba colonizada por gente afrodescendiente e indígenas procedentes de la sierra de Ayabaca y de la zona yunga de Piura.

Durante el gobierno de Agustín Gamarra (18291833) prosigue un pleito judicial contra un grupo de labradores de la tierra fronterizo con su hacienda de Tangarará. Don Fernández de Paredes es un hombre criollo, de ideas monarquistas y liberales que apoyó de manera pasiva la ruptura y la revolución política dirigida por el Intendente Torre Tagle desde Trujillo y engancharse al proyecto político de don José de San Martín que se encontraba asentado en la ciudad de Lima. Es en este tiempo político que abandona su título nobiliario de marques de Salinas y empieza a usar el titulo militar de coronel del Ejército del Perú entre los años de 1821 y 1839 y acompaña a Santa Cruz en la campaña de recolección de reclu-

4 Una entrada preliminar al tema del bandolerismo en Piura, Ayabaca y Morropón en César Espinoza Claudio 2014: 433-482.

5 Don Francisco Xavier Fernández de Paredes solicita la extinción de la Municipalidad de Querecotillo porque el pueblo se formó dentro de los terrenos de su hacienda de Tangarará. Querecotillo registra una población de 1,936 habitantes suficientes para formar un Colegio Parroquial y gozar del derecho de tener una Corporación Municipal. ARP: 1831-1833. JPI. Causas Administrativas, Caja 182, Expediente 3912; 43 folios. En adelante se registra la información con los folios citados. Una preliminar biografía política del marqués de Salinas ha sido escrita por Elizabeth Hernández García (2007). tas y el cupo en moneda-plata asignado a Piura para proseguir la guerra contra España y Fernando VII y todo parece indicar que ya estaba alejado de este gobernante durante el gobierno de la Confederación Perú-Bolivia (1836-1839). En los libros de sesiones de concejo de La Huaca se registra su presencia en el gobierno municipal. Específicamente durante el gobierno de Bolívar en el Perú participa debatiendo y eligiendo autoridades en el pueblo de La Huaca, un microespacio urbano ubicado al otro extremo del río que limitaba con su hacienda de Tangarará y que permitía la comunicación y el comercio con TumbesMáncora y la ciudad de San Miguel de Piura. Todo indica que se había alejado de la vida política que fluía en Trujillo y Lima, pero sin dejar de estar informado de los sucesos y acontecimientos que vivía la nueva república y el mundo. ${ }^{6}$

Durante el gobierno de Gamarra se ha fortalecido un esquema y estructura de gobierno heredado del tiempo de los Borbones. La capital del Departamento es ahora Trujillo y desde aquí gobierna un Prefecto y una Junta Departamental de La Libertad. En la ciudad de Piura se ha designado Subprefecto a don Tomas Cortez y desde este centro provincial se despliega otro sistema de autoridades como son los Gobernadores, un Juez de Primera Instancia y Jueces de Paz. A este aparato de gobierno nacional designado lo acompaña otro cuerpo de alcaldes, regidores y procuradores que son elegidos anualmente y en tiempos de turbulencia política designados por el prefecto o la presidencia de la república. Finalmente, en la base social y territorial se encuentran las autoridades que gobiernan los pueblos rurales y las comunidades indígenas. ${ }^{7}$

En 1783 había llegado y recorrido el valle de La Chira el obispo de Trujillo, don Martínez de Compañón quien luego de realizar el censo y el levantamiento de pequeñas capillas y concertado con los dueños de las grandes haciendas la cesión temporal de pequeños trozos de tierras, en la que pudieran residir y asentarse temporalmente numerosas familias que se dedicaban a la labranza de la tierra y al pastoreo y engorde de ganado mayor y menor, pasó

6 Otra lectura sobre la coyuntura política de la guerra contra España en Piura y la emergencia de la República puede consultarse en Elizabeth Hernández García (2008 y 2012) y Miguel Arturo Seminario 1994: 91-212.

7 Sobre el sistema de autoridades regionales y nacionales se puede consultar el trabajo de Víctor Peralta 2016: 173-190 y Alejandro Diez Hurtado 2017: 261-303. 
a recorrer otros valles costeños en su programa de evangelización y difusión del cristianismo borbónico. Uno de los asuntos problemáticos que vivían los hacendados sin resolver fue la ocupación de grandes trozos y partes de sus haciendas por cientos y miles de familias quienes atraídos por la cesión de una parcela o trozo de terreno para el ganado se dedicaba a trabajar en las tierras de orilla y secciones cultivadas con el algodonero y el maíz para la gran propiedad rural. Muchas familias llegaban de los valles de Catacaos y Sechura, pero también se asentaban campesinos parcelarios de la sierra de Ayabaca y los negros y libertos de la ciudad y haciendas de San Miguel de Piura. En este caso que estudiamos, el dueńo de la hacienda de Tangarará cedía pequeños trozos de tierra a cambio de una renta en trabajo y la entrega de un peso al año en moneda plata. Esta propiedad rural se dedicaba no solo al cultivo del algodonero sino también a la crianza y el engorde de ganado vacuno y caprino. Para esta actividad necesitaba de familias enteras que se dedicaran al arreo y conservación de los animales mayores y menores en las invernas y corrales rodeados de bosques de algarrobo y de hualtaco. Para la alimentación y la producción del forraje alimenticio se aprovecha las tierras de humedad existentes en ambas orillas del río La Chira y vecinas al pueblo de La Huaca y Amotape (José Navarro 1991). ${ }^{8}$

El año de 1825 la hacienda de Tangarará había extendido sus fronteras hacia el norte y vigilaba que sus terrenos y pastizales ubicados por el sitio y la hacienda vecina de Poechos no sea ocupada por los colonos y labradores migrantes que de manera masiva ocupaban estos lugares que gozaban de agua y de madera por la subsistencia de grandes bosques y montes con algarrobo y toda clase de frutas comestibles.

La guerra con España había movilizado a mucha gente de la sierra y de los pueblos costeños que en tiempos de baja turbulencia política se asentaban a orillas de los ríos para disponer de sus parcelas y gozar de la cosecha del maíz y el arroz y también de pequeńos hatos de ganado caprino, mular y porcino. En estos años se producirá una expansión de la frontera agraria no solo a favor de la gran hacienda sino también en el espacio que cultivan los grupos de colonos campesinos que ayudados por abogados, procurado-

8 Sobre Martínez Compañón se puede consultar a José Navarro 1991; Arellano Ignacio y Carlos Mata Indurain 2012; Macera, Pablo; Arturo Jiménez Borja e Irma Franke, 1997. res y autoridades municipales buscarían desplegar las ideas de justicia, libertad, trabajo y progreso en el campo y la ciudad en la provincia de Piura. ${ }^{9}$

A esta masa rural campesina y de colonos con ideas políticas y agraristas se suman los negros y libertos que habían integrado los batallones de Dragones del rey de España y también los milicianos que habían marchado a combatir a Pichincha y a otros lugares del Perú. Es en este juego político de construir una nueva provincia que se movilizan los agentes económicos y políticos para organizar sus grupos de poder desplegando una variedad de mecanismos que le permitan acceder a lotes de tierras con agua, caminos y mercados para su consumo. ${ }^{10}$

A los pocos ańos de haber asumido el gobierno don Agustín Gamarra, en la provincia de Piura se registra la queja de un militar y exaristócrata llamado don Francisco Xavier Fernández de Paredes denunciando que su hacienda de Tangarará había sido invadido por cientos y miles de colonos y labradores de la tierra que buscaban asentarse construyendo sus ranchos de caña y madera. Todo empezó con la iniciativa del hacendado de atraerlos con la entrega de una parcela y la obligación anual del pago de una renta que alcanzaba un peso al ańo y que estaban condicionados a que si no cumplían serian expulsados. Conforme el hacendado vio que se incrementaba el número de familias indígenas y de afrodescendientes los apoyó autorizando el levantamiento de una pequeña capilla con la finalidad de que gocen de la palabra y los sacramentos cristianos e incluso gestionó y logro que los atendiera un sacerdote con la categoría de inter de cura que se traslada desde la villa de Sullana. Recuerda el dueño de la hacienda de Tangarará que todo esto empezó con la visita de Martínez Compañón (1783) quien logró gestionar la presencia de un cura provisional para que finalmente en 1825 , la capilla y las fiestas dependieran del cura de Sullana. Se transita entonces de un tiempo histórico en la que solo había un indígena recolector de tributos hacia otro tiempo en la que los colonos campesinos y labriegos se trans-

9 Sobre bibliotecas, periódicos y libros en Piura puede consultarse a Juan Carlos Adriazola 2013: 41-48 y Vicente Requejo 1983: 5-32.

10 Frente al modelo monarquista que pretendía instaurar San Martín en el Perú, en el piedemonte andino de Piura destaca la resistencia social y política de otro líder campesino acompańado por la masa de colonos campesinos y de afrodescendientes, se trata de Isidoro Palomino de los Ríos, quien logra vincularse a don José de la Riva Agüero en 1823. Ver: César Espinoza 1982: 5-32. 
formaron en cabildantes, realizando sus elecciones y designando a sus Gobernadores, usando las autoridades el bastón y la vara de mando y coordinando acciones para el progreso con el Procurador y las autoridades judiciales y municipales de la ciudad de San Miguel de Piura. Don Francisco Xavier Fernández de Paredes, antiguamente conocido como el marqués de Salinas, y ahora bajo el estatus militar de coronel, presenta su queja y denuncia de que los habitantes del pueblo de Querecotillo se habían apoderado de una parte de sus tierras que formaban parte de su hacienda de Tangarará y que entre 1825 y 1831 no le pagaban tampoco el arriendo al que se comprometieron. De todo esto toma conocimiento el Subprefecto de Piura, don Tomás Cortez, un hombre liberal y dueño también de haciendas y negros esclavos y libertos.

Con el ascenso político al poder del Estado de Agustín Gamarra y el apoyo de un grupo de amigos y vecinos en Piura como Tomás Cortez y del Prefecto Departamental en Trujillo don Pablo Dieguez, don Fernández de Paredes se siente fuerte y protegido para recuperar no solo las tierras de su hacienda de Tangarará sino la dignidad y la honorabilidad de su estatus social frente a una masa de labradores campesinos indígenas y descendientes de negros, zambos y mulatos que se habían atrevido a instalarse en su propiedad rural, a levantar una capilla y a iniciar un proceso judicial para que el Estado les reconozca a sus autoridades elegidas y le asigne la categoría de pueblo rural y el funcionamiento de un Municipio local.

En 1831, el pueblo de Querecotillo transita hacia su institucionalización y la legitimación de un conjunto de autoridades que coordina acciones políticas de gobierno y de asuntos judiciales con las autoridades asentadas en la villa de Sullana. La Junta Municipal de Querecotillo; el Síndico Procurador cesante don Manuel Francisco Maldonado y el Gobernador de Querecotillo, don José Casariego son las autoridades representativas que intervienen para buscar una salida legal a las intenciones de suprimir el funcionamiento del gobierno local por el terrateniente y coronel de ejército don Fernández de Paredes.

En la primera parte del expediente el dueño de Tangarará trata de probar documentalmente que el territorio que ocupan los colonos campesinos de Piura le pertenece. Para este efecto adjunta documentos y testimonios de compra venta de tierras realizados por su quinto abuelo, don Francisco de Sojo entre 1683 y 1685 . Se trata de dos compras que se realizaron a Luis García y a Petrona García quienes le vendieron a don Francisco Sojo un espacio territorial que expande la hacienda hacia el norte y que ahora son ocupadas por una población de indígenas $\mathrm{y}$ afrodescendientes quienes le cambiaron el nombre por Querecotillo (f.10). En estos documentos se confirma que los García le remataron a Sojo unas tierras y pastos que existían en el río de la Chira, ubicados en la obra banda, llamadas entonces El Sapote y que son usadas para la crianza y engorde de toda clase de ganado mayor y menor $(12 \mathrm{v}) .{ }^{11}$ De igual forma, la segunda sección de estas tierras mantiene como linderos «desde un palo parado que esta como salimos de la casa que era de Diego García Martínez, mi tío, como un cuarto de legua el río arriba hasta la quebrada grande de Poechos, que es pasado el cerrillo donde tuvo Alonso Fernández su casa como vamos a Guayipirá, lo que me tocó de parte, y por la de abajo, lindan con los pastos y tierras que el dicho capitán Francisco de Sojo (f. 26) compró de Luis García, mi hermana, y la del río arriba con pedazo que le tocó a Francisco García mi hermano y quebrada en medio, según parecer por la dicha particular». En este documento de compra-venta se precisa que el bien territorial compuesto de tierras, pastos y humedades se encuentran libres de toda carga de censos y capellanías.

Don Francisco Xavier Fernández de Paredes recurre a nuevos memoriales escritos y pide que el expediente judicial sea visto en la ciudad de Trujillo y se informe al presidente y a las autoridades judiciales de la ciudad de Lima. En 17 de agosto de 1831 afirma que el sitio llamado Querecotillo está ubicado en el centro del terreno arriba señalado y que corre desde La Punta de Marcabelica hasta la quebrada de Poechos y que ahora un grupo de colonos campesinos se han propuesto despojarlo con el pretexto de que allí funciona un pueblo y su gobierno municipal.

En esta defensa escrita recuerda que años atrás la hacienda atraía gente de otros lugares para trabajar en la hacienda bajo el sistema del colonato y que a los que

11 El capitán Francisco de Sojo confirma que «se me adjudicó el dicho pedazo de tierras y pastos que está de la otra banda del río que llaman de La Chira de esta jurisdicción, que linda y corre desde La Punta de Marcabelica el río arriba, hasta tres o cuatro cuadras más arriba donde tenía su casa Diego García Martínez y llaman La Laguna de Diego García donde es el lindero... con las tierras de humedad y pastos por 250 pesos de ocho reales" (Piura 3 de julio de 1683), f.18. ARP: 1831-1833. JPI, CA, Caja 182, expediente 3912. 
llegan y se asientan se les cobraba el derecho de "piso o terrazgo" por el valor de un peso por ańo. Pero ocurre que cuando termina la guerra contra España (1824), al año siguiente regresa mucha gente a los valles de Piura buscando asentarse en tierras con disponibilidad de agua y pastos para asegurar su sobrevivencia. Entre los migrantes se encuentran familias de indígenas, mestizos y negros esclavos y libertos que se asientan desde 1825 apoyándose en los ofrecimientos de Simón Bolívar de otorgar la tierra a los poseedores. Es así que en la posguerra se reafirma políticamente el pueblo de Querecotillo y se organizan las elecciones para designar a sus autoridades y sugerir el nombramiento de los gobernadores para fortalecer las gestiones de ya no estar obligados a pagar ninguna renta al dueńo de la hacienda y obtener algunos recursos del Estado para mejorar los caminos, puentes y otras obras que contribuyan al progreso del pueblo. Señala también que en esta ocasión ha sido designado Gobernador de Querecotillo un hombre blanco y capitán de cívicos, don José Casariego quien está acompańado de vecinos honorables de este pueblo como Francisco Cruz, Juan Manuel Alburquerque y Agustín Querebalú.

Fernández de Paredes siente mucha preocupación porque en Querecotillo se está organizando un nuevo grupo de poder que no solo busca la acumulación material sino también ingresar al juego político en los colegios electorales y a la designación de las autoridades locales y municipales. Por tanto, solicita además que sobre esta inusual situación se reciba el informe del Gobernador de la villa de Sullana.

El clima social de conflicto se agudiza en estos años e informa el Síndico Procurador que por la situación política que vivió la provincia de Piura antes del gobierno de Gamarra, el alcalde y los funcionarios municipales de este pueblo no «están en ejercicio sino presos en Piura" por causa de una "asonada que se dice hicieron en meses pasados» (f. 30v).

El expediente judicial llega a la ciudad de Trujillo y las autoridades ordenan al Subprefecto de Piura que recoja más información y coordine con la Beneficencia sobre el asunto de las tierras. De igual forma, desde Trujillo se remite el expediente a la ciudad de Lima y el Fiscal Pedemonte lo devuelve señalando que el proceso debería adecuarse a los decretos sancionados por el gobierno nacional.

En esta dirección, el Gobernador de Querecotillo, don José Casariego, recoge en 15.09.1831 los tes- timonios de Juan de Campos, edad 54 años, y de Isidro Jiménez. En esta ocasión, ambos testigos coinciden en informar que el terreno ubicado en el sitio de Querecotillo está ubicado entre La Punta de Marcabelica y la quebrada de Poechos y que la poseen los colonos de la hacienda hasta el año de 1811 y que después el dueño de la hacienda la arrendó a don Mariano Tábara junto a este sitio con el de Pueblo Nuevo, y que «siguieron pagando hasta siete u ocho años en que, por las novedades de Cabildo, y nombre del pueblo se han denegado» (f. 32).

A todo esto, se suma otro hecho. Los miembros de la comisión de la Beneficencia, don Manuel de Espino y José Clemente Peralta, informan en Trujillo en 21 de agosto de 1832, que el número de habitantes del pueblo de Querecotillo es suficiente para organizar un Colegio Parroquial y que está obligado a levantar su propia Corporación Municipal (f. 41v-42).

Por tanto, frente a esta noticia, don Fernández de Paredes reitera su solicitud de suprimir la existencia del pueblo de Querecotillo, pero esta vez la gestión la efectúa ante el nuevo Subprefecto, don José de Lama y la Junta Departamental de La Libertad cuyo resultado no esperaba. En efecto, la carta enviada a la máxima autoridad departamental recomienda la atención de la solicitud de Fernández de Paredes, como puede visualizarse esta vez:

José de Lama a Muy Honorable Junta departamental de La Libertad

Trujillo 23 de agosto de 1832 .

Al Coronel Prefecto del Departamento

Adjunta a VS el expediente seguido por el señor coronel Francisco Xavier Fernández de Paredes solicitando la extinción de la Municipalidad de Querecotillo anexo a su hacienda de Tangarará para que VS., haciendo sus observaciones se sirva darle el giro que indica el acuerdo de esta $\mathrm{MHJ}$ a consecuencia de lo determinado por la Comisión de Beneficencia. Dios guarde a VS. José de Lama.

Sin embargo, desde la ciudad de Lima se ordena el cumplimiento de un nuevo decreto favorable esta vez a la gente de Querecotillo y de respaldo al informe entregado por los miembros de la Beneficencia confirmando la existencia y funcionamiento de una población de indígenas y de gente afrodescendiente en la frontera nororiental de la hacienda de Tangarará. 
A todo lo cual, al prefecto departamental, don Pablo Dieguez solo le queda ordenar al Subprefecto de Piura que evacue las diligencias que ordena el Supremo Decreto de 28 de abril de 1831 y se contraiga a la Comisión de Beneficencia de la Honorable Junta Departamental (f. 40.).

Un año después, en la ciudad de Piura, en 7.01.1833, el nuevo Subprefecto Escudero ordena que el expediente pase al Gobernador de El Cercado de Piura, de apellido Frías. Luego, ordena que el expediente pase al Dr. Pedro Jiménez y que se comunique el dictamen a las partes en 9 de enero de 1833. El Perú en esta fecha vive un nuevo tiempo político muy turbulento pero que en medio de esta tiniebla histórica no se puede olvidar que los colonos campesinos y afrodescendiente de Querecotillo habían logrado ganar temporalmente una pequeña batalla legal y política antes de llegar a la primera mitad del siglo xIx.

INFORME DE LA POBLACION EXISTENTE EN EL PUEBLO DE Querecotillo, AÑo DE I 832

\begin{tabular}{|l|c|c|}
\hline Resumen de indígenas & Número & Total \\
\hline Niñas & 28 & \\
\hline Viudas & 02 & \\
\hline Solteras & 24 & \\
\hline Casadas & 16 & \\
\hline Contribuyentes & 04 & \\
\hline Ausentes & 06 & \\
\hline Próximos & 31 & \\
\hline Niños & 09 & \\
\hline Reservados & & 129 \\
\hline Subtotal & 321 & \\
\hline Resumen de castas & 393 & \\
\hline Madres & 994 & \\
\hline Hijos & & \\
\hline Hijas & & \\
\hline Entrantes & & \\
\hline Contribuyentes & & \\
\hline Reservados & & \\
\hline Subtotal & & \\
\hline Total & & \\
\hline Es confore & \\
\hline
\end{tabular}

Es conforme y legal en todas sus partes con el Libro de Matricula de mi cargo. Piura, junio 23 de 1832 años. Miguel Delgado.
Estudio de caso B. La pequeña oligarquía de Piura persiste en conservar el sistema de la esclavitud de negros y negras dentro y fuera de la ciudad.

Daniel Cozart ha construido una tesis muy interesante en la que incorpora un capítulo titulado la "Abolición y sus descontentos: la venta de un esclavo liberado en Piura, Periù. En este trabajo se muestra y discute el impacto político de la ley de la abolición de esclavos dictado por Ramón Castilla en 1854. La tesis que sostiene Cozart es que el sistema de la esclavitud de los negros y los libertos prosigue fuera de Lima y sobre todo y de manera particular en la provincia de Piura en el transcurso del siglo XIx. ${ }^{12}$

Para este efecto, el autor presenta el caso de doña Adela Seminario quien vendió a una negra y ex-esclava llamada Mariana Raygada y Seminario, a don Ramón Días en 13 de abril de 1855, por el valor de 150 pesos en moneda plata. A los pocos días de realizado el contrato, don Ramón se informa que la negra Mariana gozaba para ese tiempo ya de la condición de mujer libre debido a la manumisión previa otorgada por el decreto de Castilla. Se inicia entonces un proceso judicial en la que Ramón Días presenta los cargos civiles y penales contra la vendedora Adela Seminario. En los recursos escritos y papeles que se encuentran en el expediente se registra el dato de que el dueño anterior no tenía conocimiento de la libertad de la negra Raygada y se le presiona para que presente la documentación que confirme su posesión y propiedad.

El contenido de este expediente muestra varios problemas no resueltos. Primero: el Juzgado de Primera Instancia de Piura no tiene conocimiento del decreto nacional emitido por Ramón Castilla aboliendo la esclavitud en el Perú cinco meses atrás. Los abogados y el fiscal guardan un silencio casi cómplice. Segundo: doña Adela Seminario y Ramón Días son dos personajes de la elite de Piura que manejan el poder judicial republicano y que lo ocurrido representa una forma velada y corrupta de eludir los decretos nacionales. Tercero: todo parece indicar que la mujer negra y ex-esclava tampoco tenía conocimien-

12 COZART, Daniel S. 2017. Afro-peruvian creoles: a social and political history of afro-descended peruvians in an era of nationalism and scientific. Universtity of New México, Albuquerque, New Mexico. Department of History. Digital Repository. Doctor of Philosophy History. http://digitalrepository.unm.edu/hist_etds/173. Consultado en 16.02.2018. 
to de la ley y de su nuevo estatus de libertad y de su condición de ciudadana. ${ }^{13}$

Para la sociedad de los negros este proceso de transición del trabajo esclavo a la del trabajo libre y asalariado tampoco dispuso de la comunicación escrita y oral respectiva. El decreto de Ramón Castilla fue radical en el propósito político que buscaba, así lo reafirma en una declaración que incrusta Cozart, con fecha de 3 de diciembre de 1854: «Hombres y mujeres hasta ahora mantenidos en el Perú como esclavos y negros liberados (libertos), cuya condición surge de haber sido transportado como tal o de haber nacido de un el útero de esclavas, que por cualquier medio están sujetos a la servidumbre perpetua o temporal, son todos sin distinción de edad a partir de hoy y siempre libres». ${ }^{14}$

A mediados del siglo XIX, en Piura todavía permanece una cultura y actitudes aristocráticas hacia los afrodescendientes; el grupo de negros que habitan en los barrios de la ciudad todavía conservan el estatus de esclavo y todo indica que las costumbres señoriales y de subordinación no cambiaron rápidamente con el decreto dictado por Ramón Castilla en 1854. En este caso la negra Mariana Raygada desconoce su propia libertad y esto explica la continuidad en su sometimiento a la esclavitud en la provincia de Piura. La abolición por género marcha lentamente y en varias direcciones. ${ }^{15}$

En la historiografía regional, Piura representa un microcosmos de la resistencia oligárquica a la abolición de la esclavitud y muestra en el accionar de los vecinos y hacendados los desafíos de no otorgar la agencia y la vida civil a los negros, zambos y mulatos después de 1855 (Santiago Távara, 1855: 33-37).

En la impugnación que realiza Ramón Días no se registra la referencia al decreto de la abolición de Castilla. El juez busca reconstruir la cadena y recorrido histórico de la propiedad y se demuestra que la negra Raygada había sido manumitida y que su «ven-

13 ARP: 1855. JPI. C.C. Leg. 239. Exp. 5189 folio 1.

14 La traducción es nuestra y para esta sección se ha reseñado las pp. 14 al 18. Peter Blanchard. 1992. Slavery and Abolition in Early Republican Peru. SR Books, Delaware, p. 195.

15 Jean-Pierre Tardieu (2004) ha publicado un libro interesante titulado «El decreto de Huancayo. La abolición de la esclavitud en el Perú, 3 de diciembre de 1854. Fondo Editorial del Congreso del Perú. Para comprender el contexto nacional se puede revisar las pp. 53-105. Otros textos revisados son los de Cano Bolívar, Julieta. 2014. Pita Pico, Roger. 2014 y 2015. Velásquez, María y Gabriela Iturralde. 2016, y Aguirre, Carlos. 2005. ta» por Adela Seminario era inválida. A todo esto, se suma el analfabetismo y la falta de conocimiento de su estatus por Raygada. En esta ocasión Adela Seminario había vendido a su negra "sirvienta» a don Días sin otorgarle el título oficial de propiedad. Sin embargo, el juez don Francisco Meneses, levanta los cargos civiles contra Adela Seminario y solo le exige verbalmente que devuelva los 150 pesos recibidos a don Ramón Días.

El juicio contra Adela Seminario le sirvió a Ramón Días para que su petición no se quede en lo monetario, sino que utiliza este proceso judicial para expresar sus ideas sobre los esclavos y el sistema de la esclavitud en Piura. En efecto, don Días señala al juez que no estaba satisfecho con su sentencia y le manifiesta que en realidad lo que había ocurrido con esta transacción era un acto criminal y de «haber mantenido a Mariana Raygada en la esclavitud ... inscribiéndola como un número entre sus bienes, y vendiéndola como tal». Por tanto, afirma que le era «indiferente si la venta era hecha a Juan, Pedro o Diego, ya que el crimen consiste en haber mantenido a una persona libre como esclava y en haberla enajenado y tratado como tal por un precio fijo». Sin mencionar explícitamente la ley de la abolición dictada por Castilla, Días parecía consciente y expresó su acusación en el lenguaje de la libertad para obtener una compensación adicional. ${ }^{16}$

Para Cozart, el decreto de Ramón Castilla del 3 de diciembre de 1854 que declara el fin de la esclavitud se implementó en varias etapas. En su libro sobre la Negritud (2008), el antropólogo Humberto Rodríguez Pastor, ha podido realizar un seguimiento a las noticias sobre el decreto promulgado por Ramón Castilla señalando que estas se dispersaron inicialmente a través de volantes impresos no oficiales. En efecto, va a ser el periódico limeño El Comercio el que por primera vez menciona el decreto recién en 18 de diciembre y finalmente publica el decreto oficial en su forma más detallada el 23 de enero de 1855. Entre las instrucciones específicas para realizar la abolición en las comunidades esclavistas se señala la creación de las «juntas de registro», unas juntas de inscripción,

16 Sobre el tema de la esclavitud y de las relaciones entre el amo y el esclavo puede consultarse el libro de Adam Smith.1995. Lecciones Sobre Jurisprudencia. Curso 1762-1763; pp. 211-230. Edit. Comares, Granada, España. 
integradas por el gobernador, un sacerdote y un vecino como testigo. ${ }^{17}$

Las Juntas buscarían recopilar una mayor información sobre los esclavos y sirvientes para luego presentarlos al registro nacional y declararlos oficialmente libres. En la práctica, Castilla sigue apoyando a la oligarquía esclavista seńalando un pago o indemnización por los esclavos/as. También reafirma su política de control y de severos castigos por los crímenes que pudieran cometer los antiguos esclavos o sirvientes. En este decreto también destaca otro artículo que ordena que los negros esclavos recién liberados y los sirvientes encargados del servicio doméstico permanezcan en los hogares actuales hasta el tiempo en que lograsen encontrar otro tipo de empleo alternativo.

La revisión y análisis de este expediente le permite verificar a Cozart la continuidad en el funcionamiento del sistema de la esclavitud en Piura. También confirma mediante este documento como las mujeres en la situación que vivía la negra Raygada podrían permanecer indefinidamente en las mismas condiciones, con un salario escaso y sin libertad de movimiento. El silencio de la burocracia judicial, de la prensa local y regional y la desinformación de los esclavos/ as revelarían la conveniencia y expectativas sociales para la pequeña oligarquía de Piura en el tiempo de la abolición impuesta por Ramón Castilla.

En los registros notariales y en los expedientes civiles y criminales, se confirma que la población afrodescendiente asume una variedad de categorías jurídicas y sociales. En los escritos y memoriales se los califica como siervos, criados o esclavos; de igual forma, ya para la segunda mitad del siglo XIX no se usa la palabra negro, zambo o mulato; tampoco se registra el origen de su etnia (angola, carabalí, criollo, etc.). La gente de color permanece viviendo en las áreas marginales de la ciudad y casi al pie de dos iglesias, San Sebastián y El Carmen que en el siglo xx empiezan a llamarlos, La Mangachería y la Gallinacera. Con la manumisión y la abolición de la esclavitud ordenada desde el Estado siguen ubicados como un sector subalterno, pobre, dependiente y con actividades laborales manuales y de servicios. ${ }^{18}$

17 Humberto Rodríguez Pastor. 2008. Negritud: Afroperuanos: Resistencia y Existencia. Centro de Desarrollo Étnico, Lima, pp. 49-51.

18 Sobre el barrio norte o de los «extramuros» llamado en el siglo xx la «Mangacheria» se puede consultar a Moscol Urbina, Jorge. 1986 y las notas y fotos de Morrey Acha, Miguel. 2013 (2018).
Cozart busca sustentar su tesis sobre el lento proceso y la permanencia para ganar la libertad por parte de los negros/as esclavas. Señala que los hombres de color encontraron muchas dificultades para superar y lograr la ansiada libertad por la vía legal e institucional a lo largo del siglo xix. Se trata de una tesis que discute las ideas planteadas por el historiador Carlos Aguirre (1993 y 2005).

Estudio de caso C. Los negros esclavos y la fuga como un arma de la esperanza y de la vida en libertad en los desiertos y montes de la provincia de Piura.

Fugar de los galpones o cabañas de la hacienda o de la vivienda-mansión levantada a orillas del río Piura o La Chira fue una alternativa que practicaron muchos esclavos/as como una forma de conquistar su libertad, aunque esta misma no lo practicara plenamente. Las fugas de negros/as y zambos/as esclavos ocurrieron en todos los ambientes que tuvieron la pieza del trabajo esclavo. En la ciudad o en el campo, los negros y mulatos esclavos usaron este método como un intento de ruptura inmediata con el cautiverio, pero practicar la fuga no les garantizaba la seguridad de obtener los medios legales a la libertad, siendo un medio precario y flanqueado por el miedo a la captura y los castigos públicos. La fuga, para el negro o cuarterón esclavo, no siempre fue exitosa, sin embargo, para el régimen esclavista tuvo un papel fundamental para su reproducción como sistema o estructura de vida y laboral. ${ }^{19}$

La acción de la fuga por los esclavos es una reacción concreta a la vida en cautiverio, minando el sistema esclavista diariamente. En el lado opuesto, los señores y los dueños de tierras y esclavos la consideraban como una afrenta y agresión a su autoridad y estatus de señores esclavistas, pues se trataba de acciones que los mostraban como agentes débiles para conservar el mando y la autoridad hacia y sobre los esclavos/as.

Los estudios sobre esta temática en Piura son todavía escasos y casi nadie se ha propuesto medir la fuga en cantidad o número, consultando los registros notariales y revisando los densos procesos judiciales conservados en el Archivo Regional de Piura. Lo que

19 ARP: 1847, JPI, CC, Caja 71, Expediente 1422. Sumario-Expediente seguido por el Síndico Procurador de esta ciudad para que se tase a la liberta Andrea León. Sobre esta materia puede consultarse los marcos conceptuales y metodológicos de Jean-Pierre Tardieu (2013 y 2018). 


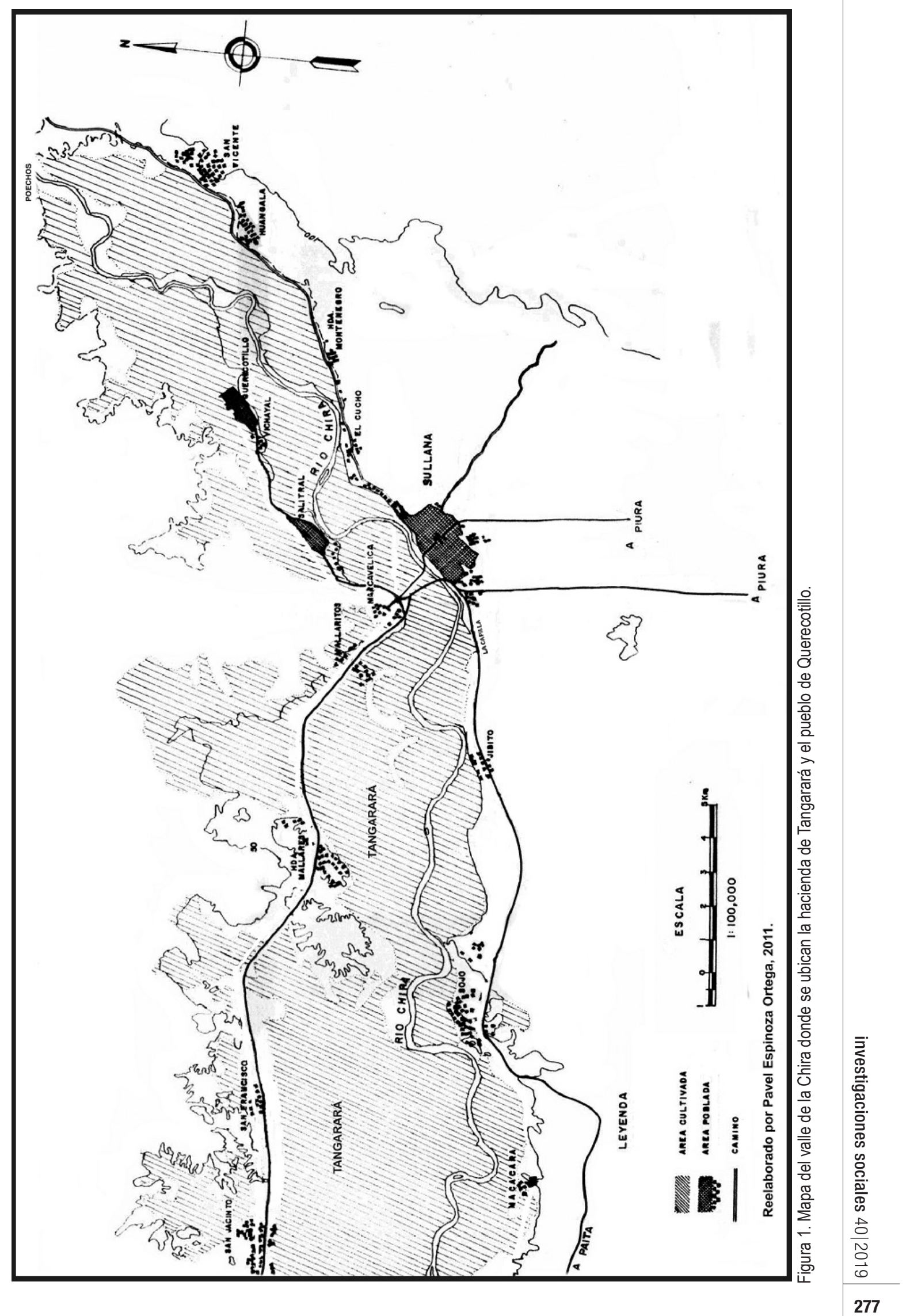


si existe son propuestas generales de estudio como la practicada por J. J. Reis quien señala que las fugas son prácticas sociales permanentes y que estas acciones son repetidas varias veces por un mismo esclavo, ya sea solo o en pequeños grupos (Reis y Silva, 1996: 65), mudándose temporalmente hacia valles los cordilleranos o pueblos alejados en dirección a Tumbes o Loja y Guarmaca. Se trata entonces de prácticas individuales y de grupos que miden muchas posibilidades para acumular dinero o bienes materiales robados a los hacendados y arrieros, y también de sujetos conscientes de toda clase de riesgos y peligros que tenían que vencer pues los hacendados y las autoridades borbónicas nunca dejaron de perseguirlos y mostrar sus cuerpos colgados en los árboles como símbolos de la justicia real española. ${ }^{20}$

Las bandas y bandoleros están conformados por sujetos de varias castas, son multiétnicas. En general, los fugitivos recorren los caminos y las quebradas de la costa y la sierra de Piura. Caminan de noche agrupados negros esclavos criollos, pardos, zambos libertos, mulatos, jóvenes y viejos. Las fugas también se producen de locales que son usados como cárceles en la ciudad de SM de Piura. En estas acciones nocturnas actúan esclavos y negros libertos de diversos colores y procedencias; se trata de un tipo de movimiento en la que todos coinciden en que la fuga sea exitosa y puedan cruzar sin mayor tropiezo el desierto de Sechura o la de Payta y Olmos. ${ }^{21}$

En estas ocasiones, algunos empiezan primero fugándose de las fábricas y tinas de jabón y de cordobanes, y otros de los campos de algodón y de las estancias ganaderas. Se trata de acciones de fuga preliminar que no son definitivas, sino usadas como un medio para escapar temporalmente y conseguir información de rutas y caminos hacia Saña o Tumbes, y terminar viviendo al pie de las cordilleras o en pequeńos poblados costeros junto a las viviendas de parceleros indígenas.

Se trata entonces de "hombres de camino" que acumulan experiencias y emociones de gozar un tiempo y de los paisajes multicolores sin la presión

20 ARP: 1821, Gobierno Político y Militar, Causas Criminales, Cuaderno 1, Legajo 1. Robo de jabón en la casa y tina de Chapallirá por el moreno José Otero.

21 Sobre la temática de los negros, zambos y mulatos, esclavos y libertos hemos publicado varios artículos que pueden consultarse en César Espinoza Claudio: 2016; 2014; 2014a. y los castigos de sus amos u amas. Estas fugas de corta duración les permitirán visitar y conocer a sus familiares o paisanos dispersos en otros valles circunvecinos luego de ser rematados en la plaza pública. Muchos aprovechan de las necesidades de la mano de obra de estancias y haciendas para trabajar en las parcelas de tierra a cambio del goce de la posesión de la moneda-plata y de animales menores con los que cohabitan en los bosques de algarrobo y hualtaco. De otra parte, muchos negros buscan la ganancia en pequeñas barras de plata y en joyas, pero también en conquistar una mujer deseada para compartir sus vidas y emociones eróticas en el campo. La fuga expresa la posibilidad de acumular mayor experiencia en el trabajo con el machete y la lampa, de incrementar pequeñas fortunas monetarias y de usar ropa nueva y de montar mulas y caballos variopintos. En Piura, la formación de grandes propiedades rurales como Tangarará o Morropón permitieron la existencia de esta singular situación de fugas temporales y de tipificar a sus actores con la categoría de delincuentes o bandidos. ${ }^{22}$

Los dueños de la tierra y esclavistas, en el valle de La Chira, registran un tipo de movimiento espacial que ya lo toman como una costumbre social de estas gentes. Se trata de negros parceleros que trabajan en lotes de tierra de la hacienda, pero también otros días en las parcelas que han construido en las orillas del río o de pequeñas lagunas cuyas cosechas le permitirán obtener ingresos monetarios adicionales. El marqués de Salinas mantiene la preocupación y vigilancia continua por el movimiento de este tipo de mano de obra especializada también en la guardianía de ganado vacuno y caprino que se desplaza entre Tangarará y Parińas, por ejemplo, y registra como "costumbre» que los negros esclavos y libertos practican este tipo de migración espacial entre varios puntos del territorio de la hacienda para asegurar el cumplimiento de la tarea asignada por los mayordomos de la hacienda. Hombres y mujeres cumplen una variedad de acciones diarias que les permitan asegurar una buena cosecha en su parcela local. Se trata entonces de un movi-

Enrique López Albújar (1973) y Raúl-Estuardo Cornejo (2011) han escrito y difundido sus tesis sobre la violencia del bandolerismo en Piura y el Perú para los siglos xviII al xx. Desde el campo literario también destacan las obras de Miguel Gutiérrez «Hombres de Caminos» (1988), y Carlos Espinoza León (1975), «Don Froilán Alama: el bandolero». 
miento de salida y de eventual retorno de la mano de obra esclava que es funcional al propietario esclavista y que expresa la adscripción servil de la mano de obra a la hacienda a cambio de la utilización de pequeñas parcelas bajo el nombre de «tierras de humedad», de bosques o circunvecinos a zonas de jagüeyes e inundaciones anuales. ${ }^{23}$

En los tiempos de escasez de mano de obra, el marqués de Salinas no puede controlar este movimiento espacial de la mano de obra negra esclava ya que este grupo humano se desplaza cotidianamente desde el pueblo de Amotape, un lugar de encuentro con la gente de Colán y Tumbes, hasta más arriba de la hacienda de Poechos, subiendo al piedemonte andino. Es al interior de estos microespacios geográficos que no solo viven los negros esclavos y libertos de varios colores, sino que, por el contrario, ante la escasez de la mano de obra, el marqués de Salinas los atrae en calidad de colonos a cientos y miles de familias indígenas de Catacaos, Sechura, Payta, Olmos y Tumbes, otorgándoles pequeńas parcelas de tierras para poder garantizar la crianza y engorde de ganado mayor y menor y la cosecha del maíz y del algodonero. En los registros notariales se encuentra la evidencia escrita de otorgarles incluso pequeños préstamos en dinero y bienes, pero también en el arriendo de trozos de tierras de orilla y humedad que presentaremos en otro ensayo.

La conexión de estas unidades productivas y la subsistencia de caminos y puentes permitirán la movilización de estas gentes para reunirse y gozar de las fiestas y de pequeñas ferias mercantiles como la que se produce en el sitio de La Huaca, La Punta y San Francisco de Chocan. Reproduce, por tanto, un ciclo de intercambio y de comercialización de las cosechas obtenidas por estas pequeñas economías rurales bajo la lógica de la ganancia en moneda plata y también para la subsistencia de sus clanes familiares. Tampoco faltaban grupos de individuos blancos, mestizos, mulatos y zambos que conforme avanza el siglo XIX se lanzan a la aventura de recorrer y salir fuera de Piura, cruzar el Partido de Trujillo y llegar a la ciudad de Lima para ofertar la venta de sus robos y adquisiciones en oro y plata.

23 ARP: 1830, JPI, CC, Expediente 161, Caja 09. Autos ordinarios que sigue la sierva Mercedes Raygada sobre que se le venda por su amo el señor don Gerónimo Seminario en la cantidad de 300 pesos, por el precio de su valor, 26 folios.
Una primera forma de libertad que encuentran los negros, zambos y mulatos esclavos es la de vivir en los barrios de arriba y de abajo formados casi al pie del río y la ciudad de San Miguel de Piura. Estamos entonces introduciéndonos a la vida social de un sector de la población esclava que busca vivir de la libertad ilegal, no de la libertad que le otorga el amo por cariño o la entrega de una cantidad de dinero. Para afirmarse en este tipo de fugas temporales, los esclavos van construyendo varias opciones para asegurarse un destino mejor a la de estar encerrado en un potrero o en una fábrica de cueros o de jabones. Estos individuos, hombres y mujeres, ensayan primero salidas a corta distancia como la de Poechos hacia Amotape para en un segundo momento cruzar el río, estacionarse en el poblado de la Huaca, avanzar a la hacienda de Sojo y salir por los Ejidos-sur de la ciudad de San Miguel de Piura. En otro momento este esclavo o bandas multiétnicas proceden a abandonar el valle de Catacaos y se mudan a Sańa o Lambayeque, otro microespacio también de residencia de muchas familias negras esclavas y libertas que han estudiado los historiadores Figueroa Luna (2001) y Luis Rocca (2010).

Esta mudanza hacia otra provincia como Saña o por el norte hacia Tumbes y Guayaquil requiere de mayor información para lograr asentarse en los pequeños palenques y convivir con los cimarrones costeños que han liberado pequeños espacios para sus familias. En los alrededores de la ciudad de San Miguel de Piura se asientan también los negros pobres que trabajan la tierra de Tambogrande, Chocholla, Texela y la hacienda de Miraflores. Al otro lado del río, se encuentran asentadas varias tinas de jabón en la que se concentran temporalmente familias indígenas y de negros esclavos y libertos que darán continuidad a un centro poblado rural informal llamado El Tacalá y después de mediados del siglo xIx bautizado con el nombre de distrito de Castilla (Miguel Pingo, 1995).

En suma, al interior de la ciudad de San Miguel de Piura se han organizado dos barrios, (La Gallinacera, o barrio Sur, y Malgache, o barrio Norte). Estos dos núcleos de gente afrodescendiente ocupan espacios periféricos al centro de la ciudad, lugares hacia los cuales se movilizan y desembocan los negros que fugan de las haciendas y estancias ganaderas del Alto Piura y la sierra de Guancabamba y Ayabaca.

Ambos microespacios en la que se encuentran asentados las familias de negros/as esclavos son luga- 


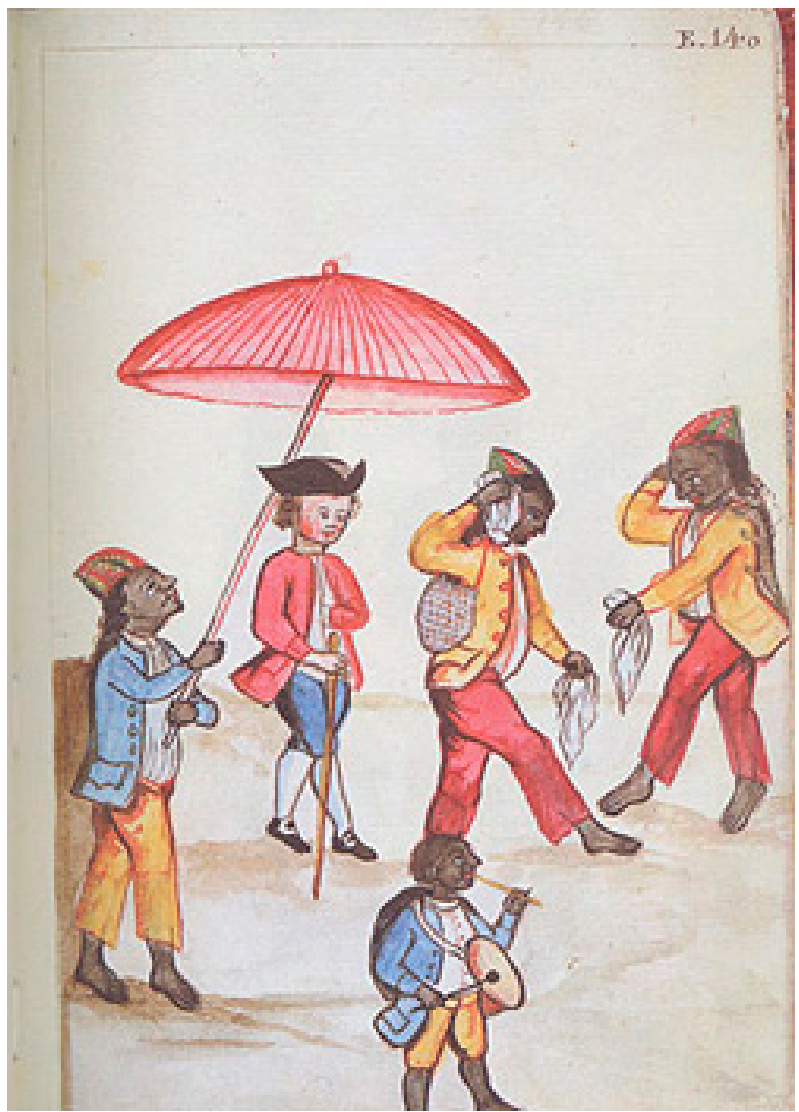

Figura 2. Martínez Compañón: «Danza de bailanegritos».

res muy atractivos para los negros fugitivos y bandoleros. Durante el siglo XVIII esta movilidad espacial y la construcción de los barrios Sur y Norte, alrededor de las iglesias de San Sebastián y El Carmen permitirán que un sector poblacional de los negros esclavos gozara de un microespacio territorial permitido por las familias blancas y los funcionarios reales de Piura pues se trataba de gente que les garantizaban la seguridad y la limpieza de esta parte de la urbe piurana.

Una primera evaluación de la fuga de los negros esclavos hacia lugares mucho más alejados nos permite plantear que se trata de una acción que les rinde mayores frutos y riquezas. Convivir con mujeres de otras castas y acumular joyas robadas a los arrieros o dueños de casas-mansiones rurales ubicados en el piedemonte andino los convierte en personajes míticos y miembros de familias mestizas.

En esta práctica de mudanzas temporales se producirán dos tipos de interacciones sociales: la primera es la ruptura de los lazos de solidaridad construidos con negros libertos, mestizos o criollos pobres. Para alcanzar lugares mucho más lejanos se declaran vivir

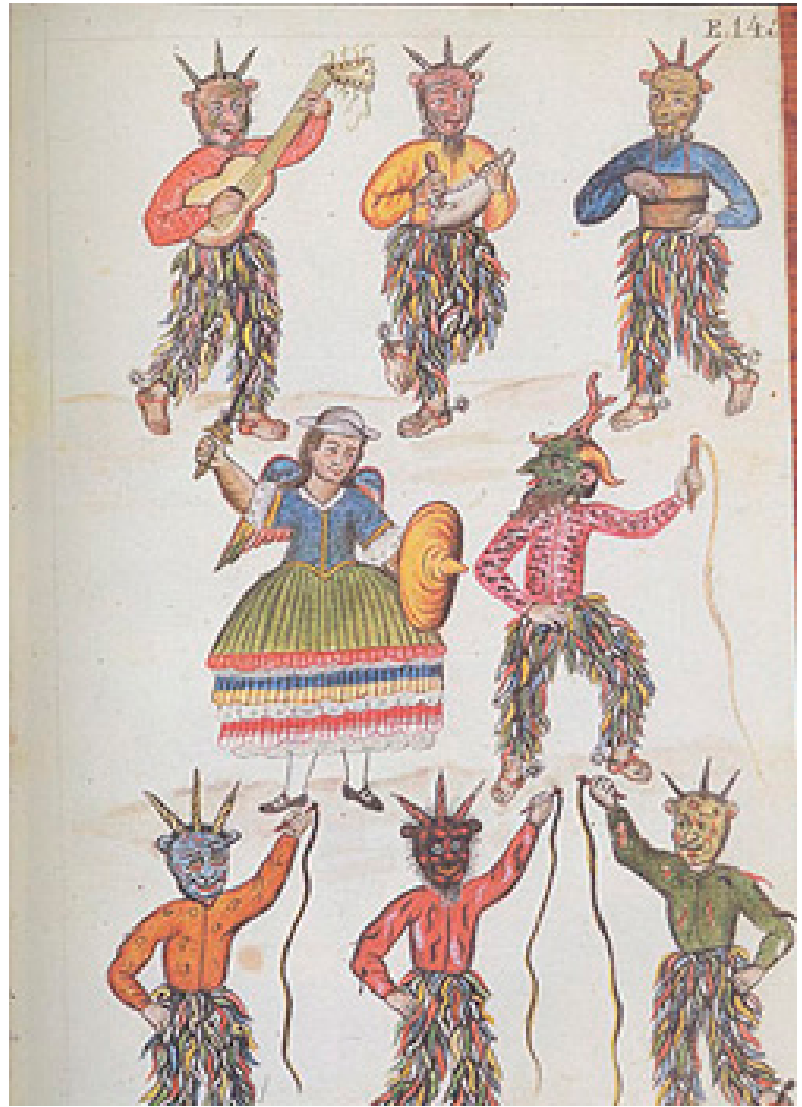

Figura 3. Martínez Compañón: «La danza de los diablicos».

en la condición de negro liberto, ahora sobrevive ya no bajo su nombre y apellido de bautizo, sino con un membrete $\mathrm{u}$ alias que se le ha impuesto por destacar en el manejo de armas de fuego, una marca en el rostro, el cambio de la vestimenta buscando imitar a los señores de la tierra, el uso de vajilla y utensilios de plata, y también de gozar de la fama de convivir con varias mujeres.

El negro esclavo y el negro liberto toman conciencia de que la fuga que realizan hacia lugares mucho más alejados de las tierras de los señores les brinda mayores frutos y ganancias. La ruptura de sus lazos de solidaridad construidos en su barrio o centro poblado y/o hacienda en la que vive el esclavo se agudizará cuando asume el estatus de negro liberto. Este tránsito lo obliga a utilizar otras estrategias para asegurar su fuga, como la de cambiar su nombre y utilizar una buena vestimenta, sombreros, alforjas de colores y mulas serranas para ocultar su origen de negro esclavo y rodearse de padrinos y compadres de casta blanca.

El mundo psíquico y subjetivo del hombre negro y esclavo goza de la percepción de los múltiples colores 


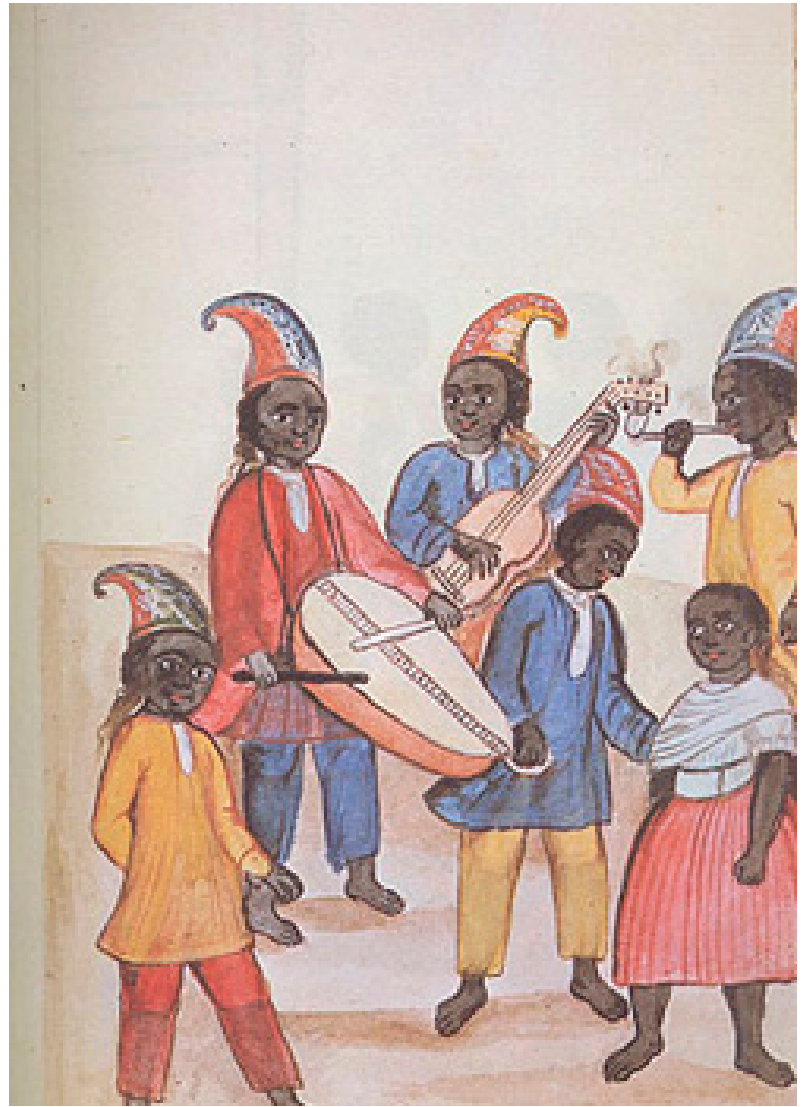

Figura 4. Códice Trujillo de Martínez Compañón: «Danza de negros».

que ofrece la llegada del día y de la noche, entonces el interior y la mentalidad de este individuo no va a aceptar ni desear regresar al mundo de la esclavitud, a una situación de permanente oscuridad porque generalmente se le mantiene encerrado, reforzando su rechazo a la vida que le han impuesto los señores esclavistas como el marqués de Salinas. Muchos hombres y mujeres viven esta experiencia emotiva y sensible de ya no poder vivir separados de la brisa del mar, del cielo y de las estrellas, de la mujer que los acompaña y de los hijos que conquistan en este nuevo tiempo de la libertad temporal rodeados de bosques y mariposas.

La decisión de trasladarse de una parcela de hacienda a otra dimensión de la vida libre implica la acumulación no solo de conocimientos sino también de emociones y sensaciones, de un capital cultural que lo impulsara a ganar nuevas relaciones sociales con el paisaje que lo rodea y también con las sensibilidades de otras gentes con las que empieza a rodearse y a convivir. Un grupo conoce el mar y goza de la brisa marina, la fuerza del sol y de los vientos que cruzan los tablazos desérticos, otros han recorrido el camino

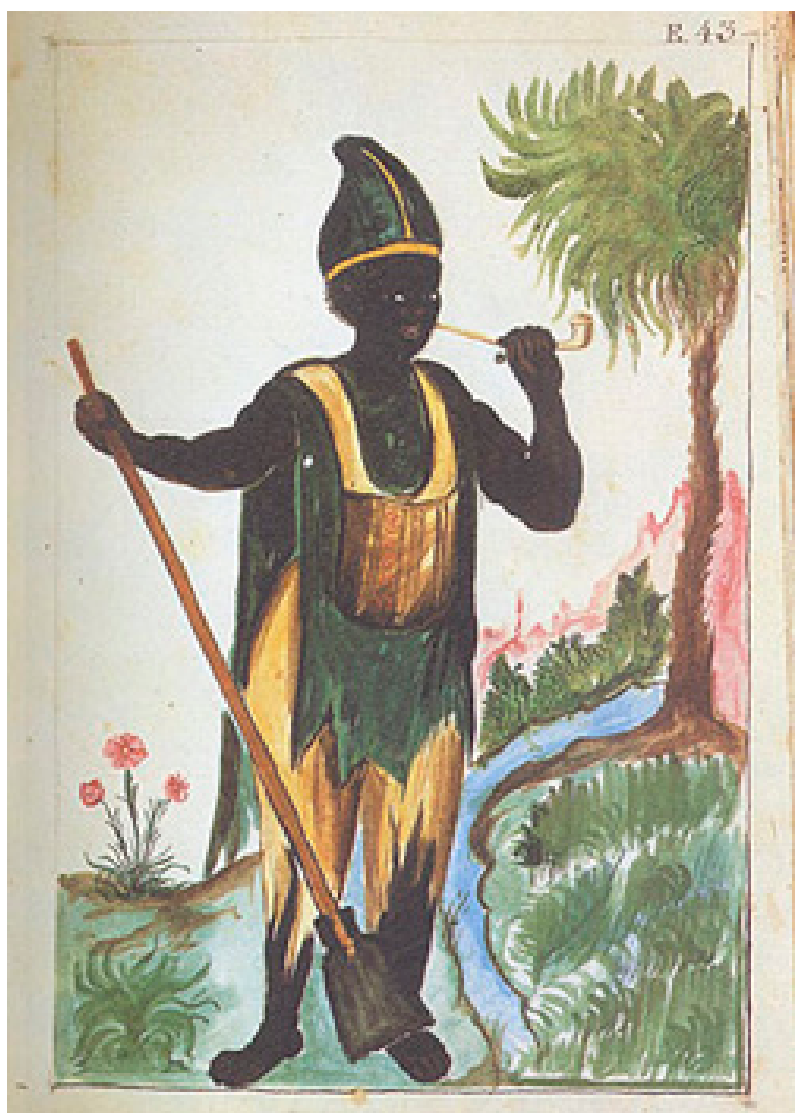

Figura 5. Martínez Compañón: «Negra», acuarela.

real de los Yngas y han gozado de los alimentos y las bebidas que proporcionan en los tambos y las chozas de los guardianes de ganado. Estas experiencias individuales les permitirán familiarizarse con el entorno natural pero también acercarse mucho más con las gentes de diferentes colores con las que conviven similar situación de las cuales ellos quieren abandonar, el trabajo de la servidumbre y de vivir como esclavos atados a la voluntad de un dueño de tierras, de un comerciante importador o de un señor noble que mira solo sus rentas y familiares blancos.

Los negros esclavos también despliegan sus sentimientos de desasosiego y de emociones al entrar en contacto con los curas y sus ayudantes que viven atosigados de las leyes borbónicas que buscan ningunearlos e invisibilizarlos. Esto puede percibirse en los expedientes judiciales revisados en la que buscando explicar u ocultar en sus testimonios orales manifiestan sus estados de ánimo y las prácticas sociales con otras personas de color diferente o amigos temporales (Aguirre y Salvatore, 2017). Recorrer el paisaje cambiante del valle de La Chira es impresionante para 
cualquier viajero que llega desde la ciudad de SM de Piura acostumbrado a vivir rodeado por los médanos desérticos. No importa por donde pueda ingresarse ya sea por las tierras de Colán o de Poechos, el asunto es que cualquier persona que lo hace siente de inmediato que se introduce a un mar espeso de árboles de muchos colores y olores y también de bosques de verde oscuro matizado con pequeñas colinas que sobresalen de los potreros de Sojo, Marcavelica, Querecotillo o Tangarará. Al fondo de estos valles se divisan colinas franqueadas por árboles y follajes que buscan marcar las fronteras de las grandes propiedades rurales que incluso llegan a extenderse más allá de la otra orilla del río de La Chira introduciéndose a Pariñas y Máncora (Cornejo, 2011, pp. 63-78)

$\mathrm{El}$ hombre o la mujer que fuga de la hacienda vive y siente el miedo y el susto de los bosques y caminos desconocidos, va conociendo lo extraño a su vida cotidiana, a veces solo intuye como llegar a la parcela o choza de otros negros/as que tiene como recomendación para recibir una ayuda para luego proseguir caminando sobre parajes y montes desconocidos. De tal forma, que los que cruzan el desierto de Pariñas para dirigirse a un centro poblado y puerto informal como Tumbes, no solo cruza campiñas o desiertos sino también espacios quebradizos en la que puede conseguir frutas y animales pequeños para sobrevivir. En este tránsito descubre el camino que une a Tangarará con Máncora y Zorritos, y aprende a diferenciar los paisajes con pendientes y los que están ocultos por los follajes de los algarrobos y los zapotes. Utiliza los senderos y caminos que rodean las parcelas dispersas de los indígenas tumbesinos, aprovecha de los mojones de piedra para descansar y gozar de los cigarrillos y el tabaco y de una pequeña reserva de aguardiente de caña o chicha que carga en sus mulas plomizas y pardas.

Salir de la ciudad de SM de Piura y luego ingresar a las tierras de la hacienda de Yapatera es una experiencia singular porque los negros encuentran y registran un terreno de montes y de quebradas, de muchos afluentes de agua que llegan al río Nacara para finalmente desembocar en lo que ahora se llama el río Piura. Por este microespacio los caminos asumen varias formas que usan el zigzag para llegar a los corrales y a las plantaciones y cuarteles de cañas que rodean a los potreros y a las invernas de ganado vacuno, mular y caprino. Entre Malingas y Yapatera se goza de bosques y paisajes maravillosos cruzados por pequeńas parcelas rodeados de árboles frutales, paltos, platanales y de mangos multicolores.

En esta parte de Piura las tierras son utilizados para la producción de pastos y de plantas que permitan la crianza y el engorde del ganado vacuno, caprino y porcino; se trata de grandes estancias ganaderas que combinan esta actividad pecuaria con la presencia de una sucesión de pequeños campos y de parcelas ubicadas sobre montes ondulados que producen pan llevar, trigo y maíz, pero también yucas y camotes para la alimentación de los trabajadores del campo. $\mathrm{Al}$ interior de estas haciendas no falta una pequeña torre y la cruz de madera que simboliza la presencia de la Iglesia Católica y la práctica de los rituales y las ceremonias cristianas. ${ }^{24}$

Los grupos de hombres y de mujeres que transitan por estas nacientes de la cordillera contemplan paisajes casi desconocidos y viven sensaciones y emociones particulares pues reciben los sonidos de aves y de toda clase de animales que viven en estos espacios geográficos. Los que viajan a la sierra no sienten miedo ni se amilanan, están seguros de portar la energía emocional y el entusiasmo suficiente pues buscan estar acompañados de los arrieros y sus mulas vigilados al son de los látigos en esta aventura de llegar a las haciendas de Guarmaca por ejemplo. Utilizan a los arrieros viajeros quienes también los observan que son gente de confianza pues reciben un pago por esta tarea y conversan sobre la buena calidad de sus trajes y del tabaco que consumen para combatir el frío cordillerano. A los serranos y campesinos blancos les llama la atención de que los negros esclavos o libertos que viajan en esta ruta usen la ropa de los señores caballeros de la ciudad de San Miguel de Piura y de que practiquen varias tareas de higiene para realizar el consumo de sus alimentos y gozar del café cargado con un poco de aguardiente de caña. Subir a la cordillera de Guancabamba también es una experiencia particular para estos grupos de negros, que no son los primeros, pues viven la sensación de un gozo especial al recorrer un espacio multicolor cubierto de neblina y de tibios rayos de sol. A lo largo del camino

24 Roux J.C. 1995. De Huancabamba au fleuve Piura: essai d'analyse de l'organisation agricole, des structures agraires et démographiques à la fin du XVIIIe siècle au Pérou. In: Cahiers d'outre-mer. $N^{\circ} 189$ - 48e année, Antilles - Tourisme; pp. 71-88; http://www.persee.fr/ doc/caoum_0373-5834_1995_num_48_189_3546. Consultado en 15.01. 2018 . 
se encuentran tambos y casas antiguas de piedra y madera, recorriendo la cordillera muchos se sorprenden del orden que existe en el manejo de estas punas y también de los riachuelos y caídas de agua que se encuentran al remontar hacia otros microterritorios como Sondor y Sondorillo (César Espinoza, 2014: 435-450).

El territorio de Guancabamba contiene paisajes ondulados, pero también cañones y quebradas impresionantes, son montańas azules y grises hermosas y escarpadas cubiertos por gruesas capas de nubes, se trata entonces de un paisaje serrano singular y multicolor que les despierta muchas sensaciones de miedo y de alegría. Al ingresar al pequeño poblado de Guancabamba se observa con mucha curiosidad la presencia de grupos de negros que manejan la yunta de los bueyes para abrir la tierra y cultivar el trigo y la caña de azúcar, acompañados de lotes de ganado vacuno y caprino encerrados en corrales de piedra y madera. Negros canosos conviven con niños mestizos cargados por sus madres que usan mantas de variados colores acompañados de mujeres adolescentes.

Para este tiempo, los negros esclavos y libertos que buscan salir de la provincia utilizan el sombrero de paja, pero también pequeños ponchos de hilo de algodón y de lana de vicuńa para protegerse de los vientos helados; carga también el negro criollo su machete y reza a los santos de su devoción buscando disfrutar del sol y de la brisa marina que azota a esta región de la costa norte del Perú. Estamos por tanto frente a un hombre de fe religiosa que empieza a conocer y a usar la razón para alcanzar un tiempo de libertad mediante esta aventura de abandonar temporalmente un lugar donde madura su vida entregando su tiempo de trabajo a otras gentes que no son de su color y estatus social.

Otra evidencia que muestra la documentación de archivo revisada es que en esta región costeńa también se formaron los llamados "palenques» pero bajo modalidades singulares a las que se levantaron en la costa centro-sur del Perú. Los negros de Piura prefieren vivir en los montes y bosques que rodeaban y se formaban en las márgenes de los pueblos como Tambogrande y Yapatera, en la que estaban asentados muchas cabañas dispersas y practicaban relaciones mercantiles y de sociabilidad con indígenas y mestizos, blancos criollos y bandoleros que cruzaban este territorio en dirección a la sierra de
Guancabamba y Guarmarca. La movilidad de individuos y de grupos de gentes de diferentes colores se produce en estas direcciones porque están seguros de conseguir la manutención y el manejo de información para su seguridad. Se trata de utilizar y construir relaciones entre las familias negras que trabajan la tierra y se dedican a la crianza de chivos y mulas como en Pabur y Huangalá, o parcelas en Sol Sol y Bigote. Para este tiempo, el latifundio de Morropón es un campo casi controlado por muchas familias de negros esclavos y libertos, que convivían procesando una compleja red social asociados a trabajadores parceleros y pequeños arrendatarios que envolvía a la gente libre y esclava.

La gente negra esclava que fuga se pone en contacto y maneja las redes de parientes y compadres para poder movilizarse y eludir a las comisiones de gentes encargadas de su captura por los subdelegados o subprefectos. Este es otro asunto también poco explorado y examinado.

La gente que fuga de la hacienda lo hacen una vez que se han establecido los contactos, a donde llegar y tener la seguridad de que encontrarían protección no solo para el sino también para su familia que lo acompañaba. Se trata entonces de la utilización de un tejido social mucho mayor de intereses y de relaciones sociales diversas en la que podían coincidir los compadrazgos, paisanajes, y gente que han recibido favores económicos y espirituales. El manejo de este tipo de interacciones les permitirá lograr conseguir la alimentación y el mantenimiento de la seguridad de su clan familiar. Son grupos humanos que administran las solidaridades, tensiones y conflictos, pero también de la decisión de fugar transitará primero desde un tiempo corto a la del manejo de distancias largas y tiempos largos para no regresar al cepo de la hacienda y recibir el castigo con latigazos y los encierros en el infiernillo (calabozo) de la Real Cárcel de Piura.

El manejo de los espacios y de las relaciones de solidaridad son muy importantes para los negros esclavos ya sean civiles o militares (pardos) en la vida cotidiana de la esclavitud. En el siglo Xvin se practicaron muchas otras formas de conseguir la libertad buscando reducir el cautiverio, la vida en el cepo, de funcionar como un animal reproductor o de sufrir castigos y vejámenes por parte de los amos/as blancos. 
¿Fue la vida social en la casa-hacienda o la emergencia de barrios negros en la ciudad los factores que permitieron facilitar la fuga de los negros buscando alcanzar la libertad temporal o total? ¿Fue el bandolerismo un tipo de acción social que les permitió acceder a una nueva cultura civilizatoria, a manejar la lectura y la escritura, a posicionarse a un sector de los amos y señores de la tierra?

Los negros esclavos y libertos en Piura están atados a la servidumbre y al trabajo forzado, pero también a una densa red de relaciones familiares, parentales y de paisanaje. Participan en los grupos festivos, en las procesiones en las cofradías y se han introducido en las milicias y en las tropas reales de España. En el esquema de la jerarquía social colonial figuran en el último piso y hasta son categorizados como parientes cercanos a Satanás. Sin embargo, los negros/as construyen nuevas relaciones sociales con los amos y con la gente que los rodea para luego utilizarlos como mecanismos y estrategias que usarían en las fugas temporales y definitivas para salir y entrar a la ciudad y a la provincia de Piura. Con estos indicadores planteo la hipótesis de que el éxito de la fuga de los negros en Piura dependía de muchos factores que no se podían reducir a las variables estructurales o contextuales sino también al papel que jugaban sus armas culturales expresada en sus emociones, sensibilidades, es decir, lo no tangible y que pueden rastrearse en los testimonios orales registrados en los procesos judiciales. El negro/a fuga porque tiene la seguridad de que alcanzará la ayuda de su red social familiar, parental, de paisanos, amigos y gente de su barrio o hacienda. Esta gente de la red y tejido social podría apoyarlo o denunciarlo, para alcanzar o liquidar su proyecto de encontrar el tiempo social de la libertad. ${ }^{25}$

Es necesario precisar para la hipótesis planteada arriba que, para finales del siglo XviII, la ciudad de San Miguel Piura y sus barrios principales estaba ocupado por la gente blanca señorial y las familias negras que cumplían labores de servicio doméstico y de seguridad. Se trata de una ciudad cuya elite dominante y oligárquica ha levantado una Iglesia central y pequeñas parroquias para las familias más ricas. La población indígena yunga y mestiza se encuentra a una

25 César Espinoza Claudio, Informe de Investigación 2017: Esclavistas y abolicionistas en un espacio regional del Perú: Piura, 1821-1824. Código: E17151031, UNMSM, Lima, Perú. distancia corta y cercana a la Iglesia de San Sebastián (antigua parcialidad de familias cañaris) y de la Iglesia de la Merced (Gerardo Gurza, 2016: 27-60). El obispo Martínez de Compañón introdujo varias reformas urbanas para mejorar la sociabilidad y la convivencia de una población multiétnica pero la presencia y el impacto del FEN en 1791 y luego una prolongada sequía liquidó este proyecto.

\section{Conclusiones preliminares}

En esta investigación se pudo avanzar en el conocimiento mucho mas específico de las formas que asume la esclavitud republicana y algunas experiencias de resistencia social y de abolicionismo practicados por esclavos/as y libertos/as en una coyuntura de construcción de la república en un espacio regional como es la provincia de Piura.

A través del estudio de casos examinamos el camino que asumen los afrodescendientes usando las leyes y la fuerza social para destruir las cadenas que los oprimen. Se revisa las manumisiones por compraventa y gracia del amo pero también otras formas de conquista de la libertad como es el movimiento social del bandolerismo en el contexto de la guerra de la Independencia. De igual forma se presenta y examina la experiencia política que viven las denominadas "castas" (mestizos, indígenas y afrodescendientes) asentados al interior del latifundio de Tangarará y el proyecto de supresión del pueblo de Querecotillo dirigido por el coronel del ejército don Francisco Xavier Fernández de Paredes.

En este artículo presentamos algunas experiencias sociales de las fugas realizadas por negros/as, desde una hacienda o estancia, pero también desde las casas-solares de la ciudad y de la Real Cárcel de la ciudad de Piura como parte de los mecanismos de resistencia y de emancipación que buscan los afrodescendientes en la provincia de Piura.

Revisando el material de archivo ubicado en Piura y Lima se ha podido verificar y reconstruir la práctica social de interrelación de los negros, mulatos y zambos con otras castas para conseguir progresivamente la emancipación de sus amos. En este objetivo de conseguir la libertad se movilizan un sector de negros libertos categorizados como la población "parda» o de "casta» y que asocian hombres y muje- 
res cuarterones y mestizos de todo color, tamaño y mezcla racial.

Todo este activismo político practicado después de 1824 representa la continuidad de la politización de la vida social y de las gentes que vive en esta región. Expresan una dinámica de continuidad de la experiencia política de la formación e instalación de un Cabildo Constitucional en el valle de La Chira (1813), precisamente en el poblado de La Punta de Marcabelica, un territorio ubicado al interior de la hacienda de La Capilla, y a la que confluirán voluntades de blancos pobres, mestizos, indígenas y negros campesinos y ganaderos de esta parte de la provincia de Piura.

Nuestra investigación aborda estos temas desde el examen de la sociedad, una perspectiva metodológica que nos permitió examinar el papel y la conducta de líderes y campesinos parcelarios y asalariados de los pueblos asentados en ambas orillas del río La Chira para resistir no solo a los hacendados sino también a un modelo de república que los excluye y discrimina.

La reconstrucción de la historia política practicada por los hacendados esclavistas y los colonos abolicionistas nos ha permitido confirmar la continuidad del modelo borbónico de la esclavitud negra en la ciudad y el campo de Piura. En los estudios de casos se registran los argumentos políticos, ideológicos y judiciales que defienden los abogados, los hacendados y comerciantes para darle continuidad a la esclavitud de los hombres de color, pero también se ha podido realizar un seguimiento a la resistencia y las formas que asumen la respuesta social de los individuos y grupos de afrodescendientes dentro y fuera de la ciudad de Piura. En buena cuenta, a comienzos del siglo XIX se encuentran dos fuerzas sociales que buscaran objetivizar la voluntad patriarcal y patrimonialista de una nueva elite, pero también en otra dirección reorientar el discurso del republicanismo en su propósito de abolir y/o cohabitar con la esclavitud de la población afrodescendiente.

\section{Bibliografía}

Adriazola, Juan Carlos (2013). El libro en Piura, una historia inacabada. Piura: Fondo Editorial de Municipalidad Provincial de Piura.

Aldana, Susana (1997). Un norte diferente para la Independencia peruana. En: Revista de Indias, No 209, pp.141-164, Madrid.

Aguirre, Carlos (1993). Agentes de su propia libertad. Los esclavos de Lima y la abolición de la esclavitud. Lima: PUCP.

Aguirre, Carlos (2005). Breve historia de la esclavitud en el Perú. Una herida que no deja de sangrar. Lima: Fondo Editorial del Congreso del Perú.

Aguirre, Carlos (2005). Silencios y ecos: La historia y el legado de la abolición de la esclavitud en Haití y Perú. En: A Contracorriente, Vol. 3, No 1, pp. 1-37. http:// www.ncsu.edu/acontracorriente/fall_05/Aguirre.pdf. Consultado en 12.12.2017.

Aguirre, Carlos y Ricardo D. Salvatore (2017). Escribir la historia del Derecho, el delito y el castigo en América Latina. En: Revista Historia y Justicia, Número 8, pp. 224-252. En: http://journals.openedition.org/rhj/923. Consultado en 08.12.2017.

AlJovín De Losada, Cristóbal; JACOBSEN, Nils (edits.) (2007). Cultura política en los Andes, 1750-1950. Lima: IFEA-UNMSM.

Arrelucea, Maribel y Jesús Cosamalón (2015). La presencia afrodescendiente en el Perú, siglos XVI-XX. Lima: Ministerio de Cultura.

Cano Bolívar, Julieta (2014). Reclamos y manumisión de esclavos en Medellín, 1800-1830. En: Cambios y Permanencias, N.o 5, Bucaramanga, pp. 495-520, Colombia.

CARAZAs, Milagros (2011). Estudios afroperuanos. Ensayos sobre identidad y literatura afroperuanas. Lima: Ediciones CEDET.

Carazas, Milagros (2004). Imagen(es) e identidad del sujeto afroperuano en la novela peruana contemporánea. Tesis de Magíster en Literatura peruana y latinoamericana, Facultad de Letras y Ciencias Humanas, UPG, UNMSM, Lima, Perú. http://sisbib.unmsm.edu.pe/ BibVirtual/Tesis/Human/Carazas_SM/Contenido. htm. Consultado en 07.01.2018.

Cenet, Centro de Desarrollo Étnico (2010). La libertad inconclusa: en torno a la esclavitud, su abolición y los derechos civiles. Lima: Cedet. 
Chiaramonti, Gabriella (2005). Ciudadanía y representación en el Perú (1808-1860). Los itinerarios de la soberanía. Lima: UNMSM, SEPS, ONPE.

Contreras, Carlos y Luis Miguel Glave (eds.) (2017). La Independencia del Perú ¿Concedida, conseguida, concebida? Lima: IEP.

Cornejo, Raúl-Estuardo (2011). Pólvora y sangre. La violencia del bandolerismo en el Perú. Siglos XVIII al XX. Piura: Grafitecnic Chávez.

CozArt, Daniel S. (2017). Afro-peruvian creoles: a social and political history of afro-descended peruvians in an era of nationalism and scientific. Universtity of New México, Albuquerque, New México. Department of History. Digital Repository. Doctor of Philosophy History. http://digitalrepository.unm.edu/hist_etds/173. Consultado en 16.02.2018

Cruz Brito, Luciana da (2013). Abolicionistas negros, a Escola Americana de Etnología e a consolidação no racismo científico nos EUA pré-Guerra Civil. En: XXVII Simposio Nacional de Historia. Conhecimento histórico e diálogo social. Natal-RN. ANPUH. Brasil.

DAWE, John y TAYLOR, Lewis (1994). Enrique López Albújar y el estudio del bandolerismo peruano. En: Debate Agrario; Número 19, pp. 135-172, Edic. CEPES, Perú.

Diez Hurtado, Alejandro (2017). De la reducción al pueblo: Procesos de conformación de grupos y territorios a raíz de la creación de Catacaos, Sechura y Colán, en la costa de Piura (norte del Perú). En: Akira Saito y Claudia Rosas (edits.). Reducciones. La concentración forzada de las poblaciones indigenas en el virreinato del Perú; pp. 261-303. Lima: National Museum of Ethnology y Fondo Editorial PUCP.

Domínguez Morante, Zózimo (2009). Análisis del carácter de los movimientos sociales en la región Piura (Perú), antes, durante y después de la guerra del Pacifico. Tesis de Maestría, Santa María de la Rábida, España. En: http://dspace.unia.es/bitstream/handle/10334/107/0064_Dominguez.pdf?sequence $=1$ Consultado en 11/06/2018.

Espinoza Claudio, César (2016). Los Borbones, los hacendados y la justicia real en Piura a comienzos del siglo XIx. La historia de vida de un zambo pardo y libre agobiado por sus amores, los jueces y la envidia de negros, zambos y mulatos. En: Investigaciones Sociales, $\mathrm{N}^{\circ}$ 36; pp. 117-138. IIHS-Facultad de Ciencias Sociales, UNMSM, Lima, Perú.

Espinoza Claudio, César (2014a). La sociedad de negros esclavos y libertos en la región de Piura. Anotaciones sobre manumisión y politización social, 1780-1812. En: Investigaciones Sociales, $\mathrm{N}^{\circ} 33$, pp. 167-185; UNMSM, IIHS, Lima, Perú.

Espinoza Claudio, César (2014). Negros esclavos y libertos en Piura. Anotaciones sobre historia política, el cimarronaje y el bandolerismo en San Miguel de Piura, Morropón, Ayabaca: 1780-1814. En: Revista de Sociología, № 24, pp. 435-482, UNMSM, Lima, Perú. Espinoza Claudio, César (2013). Historia regional e historia de la tierra. Anotaciones sobre el valle de La Chira, San Lucas de Colàn y Amotape, siglos XviIIxx. En: Arqueología y Sociedad, No 26, pp. 339-368. UNMSM, Lima, Perú.

Espinoza Claudio, César (2010). República, pueblos y municipios en Piura, siglo xIx. La experiencia política de Morropón y Chulucanas. En: Investigaciones Sociales, No 24, pp. 223-244, IIHS, UNMSM, Lima, Perú.

Espinoza Claudio, César (2005). La lucha por el algodón en las tierras tropicales de Piura. En: Investigaciones Sociales No 14, pp. 235-268, IIHS, UNMSM, Lima, Perú.

Espinoza Claudio, César (1982). Un movimiento agrarista en la Independencia de Piura: los colonos siervos de Morropon-Yapatera, 1820-1825. Piura: Edic. CIPCA.

Espinoza Soriano, Waldemar (2014). Chachapoyas frente a la Independencia politica del Perú. Lima: Ediciones Derrama Magisterial.

Fanon, Frantz (2009 [1952]). Piel negra, máscaras blancas. Madrid: Ediciones Akal.

Figueroa Luna, Guillermo (2001). Revueltas y litigios de esclavos en Lambayeque 1750-1850. En: Historia y cultura, № 24, pp. 77-108, Lima, Perú.

Flores Galindo, Alberto (1984). Aristocracia y plebe. Lima, 1760-1830. Lima: Mosca Azul Editores.

Guerra, Francois-Xavier (2009). Modernidad e Independencias. Ensayos sobre las revoluciones hispánicas. Madrid: Fundación Studium y Ediciones Encuentro, S. A.

Guerra, Francois-Xavier (1989). Hacia una nueva historia política. Actores sociales y actores políticos. Anuario del IEHS, IV, Tandil.

Gurza Lavalle, Gerardo (2016). Virginia y la reforma de la esclavitud, 1800-1865. Los límites del progreso en una sociedad esclavista. México: Instituto Mora.

Hernández García, Elizabeth (2012). Crisis de autoridad en una región periférica: la vecindad piurana frente a 
la nueva patria (Perú, 1821-1824). En: Revista Andina, №52, pp. 113-128, Cusco, Perú.

Hernández García, Elizabeth (2008). La élite piurana y la independencia del Perú: la lucha por la continuidad en la naciente república (1750-1824). Piura: PUCP. Instituto Riva-Agüero; Universidad de Piura. Facultad de Ciencias de la Educación.

Hernández García, Elizabeth (2007). El marqués de Salinas, Francisco Javier Fernández de Paredes, y su permanencia en la clase dirigente piurana a inicios de la República (1785-1839). En: BIFEA, Tomo 36 (3), pp.361-391, Lima, Perú.

KLeIn, Herbert y Ben VInson III (2008). La esclavitud africana en América Latina y el Caribe. Lima: IEP.

Kuein, Herbert S. (2016). La experiencia afroamericana en perspectiva comparada: la cuestión actual del debate sobre la esclavitud en las Américas. En: TEMPUS, pp. 308-332, Medellín.

López Albujar, Enrique (1928). Matalaché (1955). 2da. Edición. Juan Mejía Baca y P.L. Villanueva Editores, Lima.

López Albujar, Enrique (1936). Los caballeros del delito. Estudio criminológico del bandolerismo en algunos departamentos del Perú. Lima: Compañía de Impresiones y Publicidad.

Macera, Pablo; Arturo Jiménez Borja e Irma Franke (1997). Trujillo del Perú. Baltazar Jaime Martínez Compañón. Acuarelas. Siglo XVIII. Lima: Fundación del Banco Continental.

Mc Evoy, Carmen y Gabriel Cid (2016). El republicanismo en Perú y Chile: derroteros y desafíos de un proyecto en América del Sur, 1810-1895. En: Nuria Tabanera y Marta Bonaudo (coords.), Historia de las culturas políticas en España y América Latina. Vol.V: América Latina de la Independencia a la crisis del liberalismo, 1810-1930. Madrid: Marcial Pons / Universidad de Zaragoza, 313-336.

Martínez Riaza, Ascensión (ed.) (2014). La independencia inconcebible: España y la "pérdida del Perú" (18201824). Lima: Instituto Riva Agüero-Fondo Editorial PUCP.

Mamigonian, Beatriz G. (2017). Africanos livres. A abolicao do tráfico de escravos no Brasil. Sao Paulo: Companhia das Letra.

Moreno Fraginals, Manuel (1983). La historia como arma y otros estudios sobre esclavos, ingenios y plantaciones. Barcelona: Editorial Crítica.
Moscol Urbina, Jorge Eduardo (1986). Mangachería rabiosa. Piura: Piuranidad.

Navarro Pascual, José (1991). Vida y obra del obispo Martinez Compañón. Piura: Universidad de Piura.

Palacios, Guillermo (Coord.) (2007). Ensayos sobre la nueva historia politica de América Latina, siglo XIX. México: El Colegio de México, Centro de Estudios Históricos.

Paz, Juan (2002). Piura en el novecientos. Perú.

Peralta, Víctor (2016). De Prefectos a Mandatarios de la Nación. la violencia en la política peruana (18291836). En: Revista de Indias, vol. LXXVI, No 266, pp. 173-201, Madrid.

Piel, Jean (1991). «L'Histoire Régionale de Piura: Questions de Méthode, Questions d'Histoien». En: BIFEA, No 20(2), pp. 423-437, Lima.

Pita Pico, Roger (2014). La manumisión de esclavos en el proceso de independencia de Colombia: realidades, promesas y desilusiones. Bogotá: Editorial Kimpres Ltda.

Pita Pico, Roger (2012). El reclutamiento de negros esclavos durante las guerras de Independencia de Colombia 18101825. Bogotá: Academia Colombiana de Historia.

Pita Pico, Roger (2015). Fisuras y escollos en la institucionalización de la libertad de los esclavos: las Juntas de Manumisión en la provincia del Cauca, 1821-1825. En: Historia y Espacio, No 44, pp.13-41. https://dialnet.unirioja.es/servlet/articulo?codigo $=5839871$ consultado en 21/06/2018.

Ragas Rojas, José (2003). Afroperuanos: un acercamiento bibliográfico. En: Etnicidad y discriminación racial en la Historia del Perú. Tomo II; pp. 190-226. Lima: Instituto Riva Agüero y Banco Mundial.

REIs, João José (2003). Rebeliáo escrava no Brasil: a história do levante dos malês em 1835. São Paulo: Companhia das Letras, Brasil.

Reis, João José (2014). Há duzentos anos: a revolta escrava de 1814 na Bahia. En: Topoi. Rio de Janeiro, v. 15, n. 28, p. 68-115, Rio de Janeiro.

Reis, João José \& Silva, Eduardo (1996). Negociação e Conflito: A resistência escrava no Brasil escravista. Sao Paulo: Companhia das Letras.

Requejo, Juan Vicente (1983). El periodismo en Piura. Lima: Edic. Colegio de Periodistas del Perú.

Rocca Torres, Luis (2010). Herencia de esclavos en el norte del Perú: (cantares, danzas y música). Lima: Centro de Desarrollo Étnico, CEDET.

Roux J.C. (1995). De Huancabamba au fleuve Piura: essai d'analyse de l'organisation agricole, des structures agraires et démographiques à la fin du XVIIIe siècle au 
Pérou. In: Cahiers d'outre-mer. № 189 - 48e année, Antilles - Tourisme. pp. 71-88; http://www.persee.fr/ doc/caoum_0373-5834_1995_num_48_189_3546. Consultado en 15.01. 2018.

Seminario, Miguel Arturo (1994). Historia de Sullana. Piura: Municipalidad Provincial de Sullana, Maza Editores.

Tardieu, Jean-Pierre (2004). El Decreto de Huancayo. La Abolición de la esclavitud en el Perú, 3 de diciembre de 1854. Lima: Fondo Editorial del Congreso del Perú.

Tardieu, Jean-Pierre (2013). Resistencia de los negros en la Venezuela colonial: Representaciones y planteamien- tos semiológicos. Madrid: Iberoamericana; Vervuert: Frankfurt.

TARdieu, Jean-Pierre (2018). El negro Guillermo, Venezuela 1769-1771. Análisis de un discurso represivo del cimarronaje. Sevilla: Editorial Alfar.

Távara, Santiago (1855). Abolición de la esclavitud en el Perú. Edic. Biblioteca Saavedra Fajardo de Pensamiento Político Hispánico.

Velásquez, María y Gabriela Iturralde (2016). Afrodescendientes en México. Una historia de silencio y discriminación. México: Instituto Nacional de Antropología e Historia. 


\section{Anexo Documental}

\section{Señor Subprefecto}

El coronel D. Francisco Xavier Fernández de Paredes en la mejor forma ante U., parezco y digo: que en el sitio de Querecotillo, territorio de mi hacienda Tangarará construyeron ranchos en años pasado unos cuantos individuos, que por el terreno que ocupaban entraron pagando al propietario un peso cada año con la condición verbal, según lo que se observa en todas las Haciendas de la Provincia, de que, faltando al pago, o llevando nula vida, o haciendo perjuicio al Hacendado, podían ser expelidos por este sin acción a reclamar el valor de dichos ranchos. Fabricose también una capilla con permiso del mismo hacendado, y para la administración de sacramentos a aquellos vivientes se puso un sacerdote en clase de inter del cura de esta ciudad, al que el Ilustrísimo señor Obispo de esta Diócesis Don Baltasar Compañón hizo después cura provisional: y últimamente desde el año de 1825 se agregó dicha capilla y curato provisional al propietario de Sullana, del que es hoy anexo.

Por lo tocante al mando temporal, no hubo en el tiempo anterior más, que un indígena colector de tributos: pero en la transformación política se hicieron esos colonos, cabildantes por su voluntariedad y contra los Reglamentos, que solo han ordenado Municipalidades en los pueblos, y jamás en las Haciendas, y se erigió un Gobierno, que han sostenido declarándose ellos mismos a veces Gobernadores, como lo ejecutaron poco há rodando el bastón entre el alcalde y el Procurador: más como el tiempo era turbulento, fue preciso sufrir en silencio ese abuso y tropelía al propietario y esperar a mejor ocasión para el remedio. El arriendo o piso ha corrido igual suerte seis años (f.1) há que no me lo pagan porque no quieren, y creen que el carácter Municipal los autoriza para quedarse con lo ajeno: $y$ aunque el año anterior me constituí en aquel sitio con el objeto de cobrarlo, no pudo realizarse a pretexto de que no tenían dinero, y pidiendo plazos de semana en semana consiguieron a los tres meses cansarme, y que me retirase; por que hubiera apelado al medio acostumbrado de expulsar la menor amenaza contra cualquiera me habría traído un gran atropellamiento, atendida la disposición en que los miré, y los avisos que me dieron personas formales referentes a las conversaciones que habían oído.

Esto es Querecotillo, señor Subprefecto, unos hombres en ranchos de casi ningún valor, que quieren usurpar a la fuerza mi propiedad, y que yo alzaría las manos al cielo si se fueran a vivir a otra parte, o si consiguieran que U., los votase de allí: pero como lo primero es imponer y lo segundo moroso, solo me contraeré por ahora a pedir a V., la supresión de la Municipalidad y del Gobierno como providencias mero gubernativas están en sus atribuciones.

La ilegalidad de dicho cuerpo municipal no solo se funda en el ataque que con él se está haciendo a mi propiedad, causa bastantísima para su extinción, sino también en que aquellos habitantes no son aptos para obtener empleos municipales ni ser electores, porque no tienen los 300 pesos de renta que, o por una propiedad o capital correspondiente, o por el ejercicio de algún arte u oficio, o por la profesión de alguna ciencia exigen el Reglamento de Municipalidades en el artículo 80, y la Constitución en el artículo 13, y para demostración de esta verdad vea U., en los padrones cuantos de aquellos individuos satisfacen de contribución nueve pesos anuales, que es el tres por ciento, según la regla del pago, correspondiente a los 300 de renta. Porque una de dos: o los que han sido Electores y Municipales han tenido los 300 pesos de entrada, y han debido haber satisfecho los nueve de contribución, y si no lo han hecho abran estado defraudando al Fisco y deben reintegrar el déficit: o (lo que es evidente) no pagaron ni pagan los nueve pesos de contribución, porque no tuvieron ni tienen los 300 de entrada, y entonces no han podido ni pueden ser Municipales ni Electores, y ahora menos que antes, puesto que por el nuevo arreglo al cuatro por ciento han de pagarse desde este año doce pesos por el referido capital de 300. Tampoco debe haber Gobernador en Querecotillo, porque esa reunión de hombre compone una sola parroquia con la villa de Sullana de que depende ¿Cómo pueden existir dos gobiernos, uno en la capital Sullana, y otro en el anexo Querecotillo, previniendo el Articulo 134 de la Constitución, que el gobierno político de los distritos se ejerza por un ciudadano denominado Gobernador, y repitiéndolo el artículo 30 de la Ley Reglamentaria cuando dice «Las Juntas Municipales de los Pueblos cabeza de distrito que tengan Gobernador? 
Es pues una mostruosidad contraria a nuestro régimen político la existencia de dos Gobernadores en una misma Parroquia; cuando si se hubiesen arreglado los distritos, no debía haber sino uno en todo el distrito, del cual sería parte esa Parroquia entera.

Hechas pues presentes las razones de la nulidad de la Municipalidad y Gobierno de Querecotillo, pido y suplico se sirva declarar que no debió haberlos habido, ni debe haberlos en lo sucesivo, y que en las demandas de menor cuantía debe administrarse justicia por el alcalde de Sullana, nombrando la Municipalidad de esa villa el Comisionado que previene el artículo 27 de la Ley Reglamentaria para las Conciliaciones y Providencias prontas en casos ejecutivos.

Y si V., no se considera con poder para ejercitar este acto dígnese elevar este recurso a la autoridad correspondiente informando para mayor esclarecimiento de la verdad lo que le constase en el particular. Es justicia que imploro, juro no proceder de malicia (f.2).

Francisco Xavier Fernández de Paredes. Piura, febrero 16 de 1831. Elévese con informe al señor Coronel Prefecto del Departamento. Cortez. Ante mi Rebolledo. ${ }^{26}$ 